\title{
GENEL IŞLEM KOŞULLARININ YORUMLANMASI (TBK m. 23)
}

$\ddot{O Z Z}$

\author{
Fahri Erdem KAŞAK*
}

Genel işlem koşulları; sırasıyla yürürlük, yorum ve içerik denetiminden geçirilir. Genel işlem koşulunun anlamı hususunda sözleşme tarafları arasındaki uyuşmazlığın yorum yoluyla çözümlenmesi gerekir. Genel işlem koşullarında yer alan bir hüküm, birden çok anlama geliyorsa, TBK m. 23 hükmü çerçevesinde düzenleyenin aleyhine ve karş̧ tarafin lehine olacak şekilde yorumlanır. Ancak genel işlem koşulunun açı ve anlaşılır olmaması hâlinde aynı esas uygulanamaz. Bu durumda, TBK m. 23 düzenlemesinin aksine, ilgili genel işlem koşulunun geçersiz olduğunu kabul etmek gerekir. Genel işlem koşulunun birden çok anlama gelmesi hâlinde muhatabın lehine yorum kural, talî nitelikte olup sadece mutad yorum yöntemleriyle yorum uyuşmazliğ giderilemezse uygulanabilir.

Anahtar Kelimeler: Genel işlem koşulları, yorum, birden çok anlama gelme, açık ve anlaşılır olmama, düzenleyenin aleyhine ve karşı tarafin lehine yorum.

\section{INTERPRETATION OF GENERAL TERMS AND CONDITIONS (Art. 23 TCO)}

\section{ABSTRACT}

General terms and conditions are subject to validity, interpretation and content controls respectively. The dispute between the contracting parties on the meaning of a general term and condition shall be resolved by interpretation. If a provision of general terms and conditions has more than one meaning, the meaning in favor of the other party should be preferred according to Art. 23 TCO. However if the meaning of a general term and condition is not clear and understandable, the same principle cannot be applied. In this case, the general term and condition ought to be accepted invalid against the regulation of Art. 23 TCO. Interpretation against the party drawing up contract and in favor of other party rule is of secondary nature and can only be applied if the interpretation discrepancy cannot be resolved by the usual interpretation methods.

Key Words: General terms and conditions, interpretation, having more than one meaning, not being clear and understandable, interpretation against the party drawing up contract and in favor of other party.

\footnotetext{
Arş. Gör. Dr., Ankara Hacı Bayram Veli Üniversitesi Hukuk Fakültesi Medenî Hukuk Anabilim Dal1. e-posta: fahri.kasak@hbv.edu.tr

ORCID : 0000-0001-5103-4866

DOI : 10.34246/ahbvuhfd.609053

Yayın Kuruluna Ulaştığı Tarih $\quad$ : 18/07/2019

Yayınlanmasının Uygun Görüldüğü Tarih: 23/07/2019
}

Ankara Hacı Bayram Veli Üniversitesi Hukuk Fakültesi Dergisi C. XXIII, Y. 2019, Sa. 3195 


\section{GíRIŞ}

19. yüzyılda ortaya çıkması nedeniyle çoğu hukukî kuruma göre yeni olarak nitelendirilebilecek genel işlem koşullar1 ${ }^{1}$, uygulamada sıkça karşımıza çıkmaktadır. Eskiden sadece tüketici hukuku içerisinde ${ }^{2}$ değerlendirilen ve yalnızca taraflardan birinin tüketici olduğu sözleşmelerle sinırlı olarak uygulanan genel işlem koşulları; TBK'nin 01.07.2012 tarihinde yürürlüğe girmesi ile birlikte tüm borç ilişkilerine uygulanabilir bir konuma kavuşmuştur.

Bilhassa Alman hukukunda kapsamlı bir şekilde incelenen genel işlem koşulları, ilk olarak AGBG ile düzenlenmiş̧iri ${ }^{3}$ Anılan kanunun hükümleri, daha sonra BGB'nin modernleştirilmesi kapsamında $\S \S$ 305-310 hükümleri olarak BGB metnine alınmıştır. İsviçre hukukunda ise böyle genel bir kanunî düzenlemeden bahsedebilmek mümkün değildir ${ }^{4}$. Nitekim TBK'de genel

1 Genel işlem koşullarının tarihî gelişimine dair ayrıntılı açıklamalar için bkz. SCHULER, s. 24-48. Öğretide ve uygulamada yerleşmiş olan "genel işlem şartları" kavramının kanun koyucu tarafından niye tercih edilmediği izaha muhtaçtır. Aynı doğrultuda bkz. ATAMER, (2012), s. 9 dn. 1.

2 Bu bakımdan "sözleşmedeki haksız şartlar" kenar başlığına sahip eTKHK m. 6 hükmü belirtilmelidir. 28.05.2014 itibarıla yürürlüğe giren TKHK ise "tüketici sözleşmelerindeki haksız şartlar" kenar başlıklı m. 5 hükmüyle, benzer şekilde sadece tüketici sözleşmeleri bakımından genel işlem koşullarını düzenlemiştir. Öte yandan eski tarihli Yargıtay kararlarında da genel işlem koşulları meselesi ele alınmış ve kanunî bir düzenleme bulunmasa bile hâkimin genel işlem koșullarına müdahale edebileceği belirtilmiştir. Örnek olarak bkz. Yarg. 3. HD, T. 02.06.1998, E. 1998/4263, K. 1998/6098: "Prensip olarak Türk hukukunda genel işlem şartları hakkında önceden idari kontrolün veya sonradan yargl kontrolünün yapılmasını öngören bir yasal düzenleme mevcut değildir. Bu durumda genel işlem şartlarındaki kayıtların kontrolü, ancak dava halinde, özellikle kayttların yorumu, tamamlanması ve değiştirilmesi veya geçersiz sayılması hâkimin görevine dâhil olmaktadır. Gerek Ülkemizde, gerek Alman ve İsviçre Mahkemeler içtihatları ile bilimsel ögretisinde, genel işlem şartlarının uyuşmazlık halinde hâkim tarafindan kontrolünde, açık olmayan kayıtların geçersiz, şaşırtıcı kayıtların ise sözleşmenin içeriğinden sayılmayacağı, münferit sözleşmedeki hükümlere aykırı olan kayıtların uygulanmayacăğ, kişilik haklarını sınırlayan kayıtların hükümsüz olacağı ilkeleri geliştirilmiş ve uygulanmıştır."

3 09.12.1976 tarihinde çıkarılan AGBG, 01.04.1977 tarihinde yürürlüğe girmiş ve 01.01.2002 tarihinde yürürlüğe giren kapsamlıBGB değişikliklerine kadaryürürlükte kalmıştır. Buhususta bkz. GUHL/KOLLER/SCHNYDER/DRUEY, § 13 N 53; KOCAYUSUFPAŞAOĞLU, § 23 N 8.

4 İsviçre hukukunda, Alman hukukunun aksine kapsamlı bir genel işlem koşulları kanunu veya düzenlemesi bulunmadığ1 yönünde bkz. HUGUENIN/MEISE, Art. 19-20 N 23; KOCAYUSUFPAŞAOĞLU, § 23 N 8; KOLLER, N 23.01. Genel işlem koşulları bakımından İsviçre hukukundaki yegâne düzenlemenin 01.07.2012 tarihinde yürürlüğe giren Art. 8 UWG olduğu yönünde bkz. GUHL/KOLLER/SCHNYDER/DRUEY, § 13 N 53; HUGUENIN/ MEISE, Art. 19-20 N 23. Art. 8 UWG hükmüne dair açıklamalar için bkz. KOLLER, N 
işlem koşullarını düzenleyen hükümler, Alman hukukundaki düzenlemeleri takip etmiştir ${ }^{5}$ Bu bakımdan İsviçre sistemiyle büyük ölçüde örtüşen TBK'nin, Alman menşeli genel işlem koşulları hükümlerini örnek alması eleştiriye açıtır ${ }^{6}$.

Genel işlem koşullarının yorumlanması, Alman hukukunda "şaşırtıcı ve çok anlama sahip hükümler" ("überraschende und mehrdeutige Klauseln") kenar başlığına sahip § 305c BGB hükmünde düzenlenmiştir. Anılan hükmün ilk fikrası, sözleşmenin niteliğine ve işin özelliğine yabancı genel işlem koşullarını (TBK m. 21/II) düzenlemektedir ${ }^{7}$. Konumuzu teşkil eden genel işlem koşullarının yorumlanması (TBK m. 23) meselesi ise anılan hükmün ikinci fikrasında kendine yer bulmuştur.

$\mathrm{Bu}$ çalışmada yalnızca genel işlem koşullarının yorumu işlenmiş olup genel işlem koşullarının içerik ve yürürlük denetimi ele alınmamıştır.

23.57-23.67. Art. 8 UWG düzenlemesinin tüketici sözleşmelerine uygulandığı; ancak tüketici sözleşmesi dışındaki sözleşmelerde de gizli içerik kontrolü yapılabileceği yönünde bkz. HUGUENIN/MEISE, Art. 19-20 N 23. Art. 8 UWG düzenlemesine ek olarak Art. 256/ II/a OR, Art. 288/II/a OR ve Art. 3 VVG hükümlerinin İsviçre hukukundaki az sayıdaki genel işlem koşulu düzenlemelerine örnek gösterilebileceği yönünde bkz. KOLLER, N 23.01. Söz konusu örneklere Art. 33 VVG hükmü de eklenebilir. Bu çerçevede bkz. HUGUENIN, § 6 N 630; GAUCH/SCHLUEP/SCHMID, N 1231; KRAMER/PROBST/PERRIG, N 253; GUHL/KOLLER/SCHNYDER/DRUEY, § 13 N 52; BGE 115 II 264 E. 5a. Yasalaşamayan OR2020, Art. 32-33 hükümlerinde genel işlem koşullarına ilişkin genel bir düzenleme öngörmüştü. Bu hususta bkz. GAUCH/SCHLUEP/SCHMID, N 1144 dn. 368.

5 TBK m. 20 gerekçesi: “... Alman hukukunda daha önce özel bir kanunla düzenlenmiş olan genel işlem koşullarl, belirtilen hükümler de göz önünde tutularak, Alman Medenî Kanununun ( $B G B) 305$ ve devamı maddelerinde genel hüküm niteliği kazandırılarak yeniden düzenlenmiştir. Böylece, söz konusu hükümlerin uygulama alanının sadece tüketicilerle sinırlı kalması önlenmiştir."

6 Genel işlem koşullarında İsviçre örneğinden ayrılmaya neden ihtiyaç duyulduğu ve TBK düzenlemesiyle genel işlem koşullarının sadece tüketici sözleşmeleriyle sınırlı olan uygulama alanının neden aşırı ölçüde genişletildiği cevapsız bırakılmıştır. TBK m. 20 hükmünün gerekçesi "Tasarıda, genel işlem koşullarının tâbi olduğu geçerlilik kuralları, bunlara aykırılığın yaptırımları ve genel işlem koşullarının yorumlanması gibi konuların açıklı̆̆a kavuşturulması amacıyla, bütün sözlesmeleri kapsayacak emredici genel hükümler seklinde düzenlenmesi zorunlu görülmüștür." ifadeleriyle kanaatimizce doyurucu olmayan bir açıklama yapmıştır.

7 Mutad olmayan hükümler (ungewöhnliche Klauseln) veya mutad olmama kuralı (Ungewöhnlichkeitsregel) şeklinde de ifade edilen ilkeye dair açılamalar için bkz. JÄGGI/ GAUCH, Art. 18 N 472 vd.; KRAMER/ SCHMIDLIN, Art. 1204 vd.; HUGUENIN/MEISE, Art. 19-20 N 27; KAŞAK, s. 420 vd.; KAPLAN, (2013), s. 78-79; BGer 4C.282/2003 E. 3.1; BGE 119 II 446 E. 1a. 


\section{Genel İşlem Koşullarının Yorumlanması}

\section{A. Yorumun Şartları}

Genel işlem koşullarının denetimi üç aşamadan oluşur: Genel işlem koşullarıyla ilgili uyuşmazlıklarda öncelikle genel işlem koşullarının yürürlük denetimi yapılır. Sözleşmenin bir parçası hâline geldiği tespit edilen genel işlem koşulları -ihtiyaç varsa- yorumlanır ve daha sonrasında da anılan koşulların içerik denetimi yapılır ${ }^{8}$.

Yorumun amacı, sözleşme içeriğine dâhil olmuş genel işlem koşullarının anlamlarına ilişkin taraflar arasındaki uyuşmazlığı çözmektir. Bir başka ifadeyle, sözleşmenin zayıf tarafının korunması, yorum aşamasının doğrudan amaçları arasında yer almaz. Esasen sözleşmenin zayıf tarafının korunması, içerik denetimi ile sağlanabilir. Bu çerçevede genel işlem koşullarının yorumu sonucunda elde edilecek sözleşme içeriğinin, içerik denetimini aşamayacağ 1 görülürse yorum üzerinde daha fazla emek harcamaya gerek kalmaz'. Zira genel işlem koşulları nasıl yorumlanırsa yorumlansın içerik denetimi aşamasında zaten geçersiz sayılacaklardır.

8 Yarg. 11. HD, T. 21.05.2018, E. 2016/11123, K. 2018/3743 (“Bir sözleşme hükmünün genel işlem koşulu niteliğinde olduğunun anlaşılması halinde, genel işlem koşullarının üç aşamalı denetime tabi tutulması gerekir. Söz konusu denetim aşamalarl; yürürlük (kapsam) denetimi, yorum denetimi ve içerik denetimidir."); Yarg. 11. HD, T. 23.01.2018, E. 2016/13088, K. 2018/563 ("Sözleşmede, yürürlük denetiminin aşılması ve yorumu gerektirecek bir belirsizliğin bulunmaması veya bulunsa bile düzenleyen aleyhine yorum yapılmış olmasından sonra, sözleşmenin bir de "içerik" denetimine tabi tutulması gerekmektedir."); Yarg. 11. HD, T. 04.06.2018, E. 2016/13006, K. 2018/4273 (“Taraflar arasinda düzenlenen sözleşmenin genel işlem koşulu taşıdığının kabulü halinde genel işlem koşulları bakımından yürürlük (kapsam), yorum ve içerik denetimine tabi tutulması gerekir."); LOCHER, s. 60; BAUER, s. 47-48; KOCAYUSUFPAŞAOĞLU, § 23 N 10; ATAMER, (2001), s. 124; ATAMER, (2004), s. 292; ATAMER, (2012), s. 11; ATAMULU, s. 110; AKÇAAL, s. 55; YELMEN, s. 112. Yürürlük denetiminin konusu genel işlem koşullarının sözleşmenin içeriğine dâhil olup olmadığının tespitidir. Ancak taraflar arasındaki sözleşmenin içeriğine dâhil olan bir genel işlem koşulunun yorumlanması söz konusu olabilir. Yürürlük denetimi yapılmaksızın genel işlem koşullarının yorumlanması aşamasına geçilemez, zira aksi hâlde belki de yürürlük denetimini geçemeyecek ve bu nedenle sözleşmenin içeriğine dâhil olamayacak genel işlem koşullarının yorumlanması ile beyhude uğraşılmış olunur. İçerik denetiminin konusu genel işlem koşullarının geçersiz sayılıp sayılamayacağına ilişkindir. Kısacası genel işlem koşullarının sırasıyla yürürlük denetimi (Geltungskontrolle), yorum denetimi (Auslegungskontrolle) ve içerik denetiminden (Inhaltskontrolle) geçirilmesi gerekmektedir. Genellikle üç aşamalı bir değerlendirme öğretide kabul edilse de yorum denetimini hiç zikretmeyip sadece yürürlük ve içerik denetiminden bahsedenler de vardır. Bu doğrultuda bkz. BÜHRER, N 24-27. Boşuna çaba sarf edilmesini önleyeceği için anılan üçlü sıralamaya uymanın önemli olduğu yönünde bkz. Yarg. 11. HD, T. 21.05.2018, E. 2016/11123, K. 2018/3743; ATAMER, (2001), s. 124; YELMEN, s. 112.

9 ATAMER, (2004), s. 301-302; ATAMER, (2012), s. 37-38; ATAMER, (2001), s. 136-137.

198 Ankara Hacı Bayram Veli Üniversitesi Hukuk Fakültesi Dergisi C. XXIII, Y. 2019, Sa. 3 
Genel işlem koşulunun yorumlanması meselesinin gündeme gelebilmesi üç şartın varlığına bağlıdır: Yapılan sözleşmede genel işlem koşulları kullanılmalı, genel işlem koşulunun düzenlediği hususta bireysel bir anlaşma yapılmamalı ve genel işlem koşulunun anlamı üzerinde taraflar arasında bir uyuşmazlık bulunmalıdır.

\section{Genel İşlem Koşulunun Mevcudiyeti}

Genel işlem koşulunun yorumlanmasının ön şartı, sözleşmenin genel işlem koşulu içermesidir ${ }^{10}$. Bu bağlamda yorumlanacak sözleşmede genel işlem koşulu yer almıyorsa artık genel bir kurum olan sözleşmenin yorumlanması gündeme gelir.

Genel işlem koşulu kavramı, TBK m. 20/I hükmünde "bir sözleşme yapılırken düzenleyenin, ileride çok sayıdaki benzer sözleşmede kullanmak amacıyla, önceden, tek başına hazırlayarak karşı tarafa sunduğu sözleşme hükümleri" ş̧eklinde tanımlanmıştır. Öğretide ${ }^{11}$ ve yargı kararlarında ${ }^{12}$ da benzer tanımlara rastlanmaktadır ${ }^{13}$.

10 İsviçre Federal Mahkemesi'ne göre sadece matbu sözleşmelerde birden çok anlama gelme kuralının uygulanabileceği yönünde bkz. KRAMER/SCHMIDLIN, Art. 1 N 109; ATAMER, (2001), s. 138-139; BGE 99 II 292-293 E. 5. Bu kuralın uygulanabilmesi için hükmün, bir tarafça kaleme alınması veya kullanılması gerektiği doğrultusunda bkz. GAUCH/ SCHLUEP/SCHMID, N 1231; JÄGGI/GAUCH, Art. 18 N 453, 455; EREN, s. 494. Bu bakımdan taraflar sözleşme metnini birlikte oluşturmuşlarsa veya hükmü müzakere etmişlerse birden çok anlama gelme kuralının uygulanamayacağı yönünde bkz. GAUCH/SCHLUEP/ SCHMID, N 1232; KOLLER, N 23.56; JÄGGI/GAUCH, Art. 18 N 455; TERCIER/ PICHONNAZ/DEVELIOĞLU, N 951; ATAMER, (2004), s. 301; BGE 99 II 293 E. 5. Keza hükmün noter gibi üçüncü bir kişi tarafindan önerilmesi hâlinde de birden çok anlama gelme kuralının uygulanamayacağı yönünde bkz. KOLLER, N 23.56. Anılan hâllerde birden çok anlama gelen sözleşme hükmü üzerinde tarafların irade beyanları uyuşmamış olduğu için ilgili hükmün geçersiz olacağı yönünde bkz. KOLLER, N 23.56; ATAMER, (2004), s. 301. Birden çok anlama gelme kuralının uygulanabilmesi için genel işlem koşullarını kullananın, onları bizzat yazmış ya da yazdırmış olması elzem değildir; genel işlem koşullarını sadece kullanması kâfidir. Bu yönde bkz. ve krş. GAUCH/ SCHLUEP/SCHMID, N 1233-1234; BASEDOW, § 305c N 48. Şayet uyuşmazlık sözleşmenin ikincil bir noktasına ilişkinse hâkimin yedek hukuk kuralı veya tamamlayıcı yorumla sözleşmeyi tamamlayabileceği yönünde bkz. ATAMER, (2004), s. 301.

11 GAUCH/SCHLUEP/SCHMID, N 1117; SCHÖNENBERGER/JÄGGI, Art. 1 N 489; HUGUENIN/MEISE, Art. 19-20 N 23; JÄGGI/GAUCH, Art. 18 N 463; KRAMER/ SCHMIDLIN, Art. 1 N 182; HUGUENIN, § 6 N 605; BERGER, N 944; OĞUZ, s. 9 vd;; ATAMER, (2001), s. 61; ATAMER, (2012), s. 12 vd.

12 Yarg. 11. HD, T. 23.01.2018, E. 2016/13088, K. 2018/563; Yarg. 3. HD, T. 18.12.2014, E. 2014/13539, K. 2014/16751; Yarg. 13. HD, T. 29.04.2014, E. 2014/13315, K. 2014/13503; BGer 4C.282/2003 E. 3.1; BGer 4P.135/2002 E. 3.1.

13 Genel işlem koşulu içeren sözleşmelerin sıklıkla "formüler sözleşme" (Formularvertrag) 


\section{Genel İşlem Koşulunun Düzenlediği Hususa İlişkin Olarak Herhangi Bir Bireysel Anlaşmanın Bulunmaması}

Tarafların yapmış olduğu bireysel anlaşmaların, genel işlem koşullarına nazaran öncelikle uygulanacağı (Vorrang der Individualabrede) § 4 AGBG ve $\S 305 \mathrm{~b}$ BGB hükümlerinde açıkça düzenlenmiştir ${ }^{14}$. İsviçre ve Türk hukuklarında bu konuda bir düzenleme bulunmamakla birlikte aynı esas, gerek öğreti gerek yargı kararları tarafından kabul edilmektedir ${ }^{15}$. Esasen genel işlem koşulları, yalnızca tarafların üzerinde uzlaşması ile sözleşmenin bir parçası hâline gelip hüküm ifade edebilir ${ }^{16}$. Bu bağlamda tarafların yapacakları bir bireysel anlaşma ile herhangi bir genel işlem koşulunun uygulanmamasını kararlaştırmaları mümkündür ${ }^{17}$. Bir başka ifadeyle, tarafların yaptıkları

veya "standart sözleşme" (Standardvertrag) olarak anıldığı yönünde bkz. KOLLER, N 23.08. TBK m. 20 hükmünün gerekçesinde ise bu minvalde "tip sözleşme", "kitle sözleşme", "katılmalı sözleşme" ya da "formüler sözleşme" kavramlarının da kullanıldığı belirtilmiştir. Aynı doğrultuda bkz. Yarg. 3. HD, T. 18.12.2014, E. 2014/13539, K. 2014/16751; Yarg. 13. HD, T. 29.04.2014, E. 2014/13315, K. 2014/13503.

14 BASEDOW, § 305c N 39; WIEGAND, s. 335 dn. 21; ATAMER, (2001), s. 125; ATAMULU, s. 111.

15 Yarg. 11. HD, T. 14.04.1995, E. 1995/1993, K. 1995/3369 (“Italyan ve Alman hukuklarinin aksine İsviçre-Türk Borçlar Hukukunda bu konuda genel veya özel bir hüküm yoktur. Genel kabule göre, taraflar genel işlem şartlarının aksini sözleşmenin bir maddesi ile kabul etmişlerse bu kabulleri geçerlidir ve önce aksi kararlaştırılan bu özel kuralın, genel işlem şartlarındaki kurallardan önce uygulanmasi gerekir.”); HUGUENIN, § 6 N 613, 628; STUCKI, s. 26; ATAMULU, s. 126; KRAMER/SCHMIDLIN, Art. 1 N 182, Art. 18 N 61; SCHWENZER, N 45.09; KOCAYUSUFPAŞAOĞLU, § 23 N 20; BGE 135 III 228 E. 1.4; BGE 125 III 266-267 E. 4b/bb; BGE 123 III 44 E. 2c/bb. Bireysel anlaşmay1 genel işlem koşuluna göre özel bir hüküm olarak nitelendirip özel hükmün genel hükümden önce uygulanacağı ilkesi (lex specialis derogat lex generali) ile aynı sonuca ulaşılması için bkz. BERGER, N 955; RAISER, s. 230-231. TMK m. 2 hükmüne dayandırılan ve kimsenin kendi davranışları ile çelişkiye düşemeyeceği (venire contra factum proprium) yasağı çerçevesinde benzer sonucun elde edilebileceği yönünde bkz. KRAMER/PROBST/ PERRIG, N 247; SCHWENZER, N 45.09; KRAMER/SCHMIDLIN, Art. 1 N 210.

16 SCHULER, s. 121.

17 Şüphesiz bu başlık altında yapılan açıklamalar, sözleşmede yer alan genel işlem koşullarından herhangi birini değiştirmek amacıyla bireysel anlaşma yapılmaması gerekliliğine ilişkindir. $\mathrm{Bu}$ çerçevede yapılan bireysel anlaşma, genel işlem koşullarının düzenlediği hususlardan hiçbiriyle ilişkili değilse genel işlem koşulunun yorumlanabilmesi için gerekli olan "bireysel anlaşma ile değiştirilmeme" şartı yine gerçekleşmiş olur. Tam tersi şekilde, yani yapılan bireysel anlaşmalarla genel işlem koşullarının tamamı değiştirilirse bu sefer de sözleşmede genel işlem koşulu kullanılmamış olacağı için bunların yorumlanabilmesi de söz konusu olamaz. Bireysel anlaşma örnekleri için bkz. ATAMER, (2001), s. 124 dn. 2. Bireysel anlaşmanın sözlü veya yazıll, açık veya zımnî, sözleşmenin kurulmasından önce veya sonra yapılabileceği yönünde bkz. KRAMER/PROBST/PERRIG, N 245; LOCHER, s. 55-56; ATAMER, (2001), s. 126. Genel işlem koşullarından ayrılan şahsî bir anlaşmanın 
bireysel anlaşmalar, genel işlem koşullarına göre öncelikli olarak uygulanır ${ }^{18}$. $\mathrm{Bu}$ bakımdan bireysel anlaşmanın, ilgili genel işlem koşulunun tam tersini kararlaştırması gerekli değildir; bireysel anlaşmanın genel işlem koşulundan sapması ya da genel işlem koşulunu sınırlandırması hâllerinde de genel işlem koşulu sözleşme içeriğine dâhil olamaz ${ }^{19}$. Böylece bireysel anlaşma, kendisiyle çelişen genel işlem koşulunun sözleşme hükmü hâline gelmesini engeller ${ }^{20}$. Zira anılan genel işlem koşulu üzerinde, TBK m. 1/I hükmü uyarınca tarafların karşılıklı ve birbirine uygun irade beyanları bulunmamaktadır. Böyle bir durumda sözleşme içeriğine dâhil olmayan, yani yürürlük denetimi aşamasını geçemeyen genel işlem koşulunun yorumlanması da söz konusu olamaz ${ }^{21}$. Şu hâlde genel işlem koşullarını içeren sözleşmenin bu hâliyle hüküm ifade ettiği konusunda hiçbir şüphe kalmadıktan sonra anılan koşulların yorumu aşamasına geçilebilir.

Genel işlem koşulunun, tarafların yaptığı bireysel anlaşmaya göre muhatap için daha avantajlı olması, bireysel anlaşmanın uygulanmaması sonucunu doğuramaz; zira esas olan taraf iradeleridir ${ }^{22}$. Bu bakımdan bireysel anlaşmanın, muhatabın daha lehine ya da aleyhine olması önem arz etmez ${ }^{23}$. Ekonomik açıdan zayıf olan muhatabın korunması mantıklıdır; ancak bu tarafin, yaptığı anlaşma ile genel işlem koşullarına göre daha aleyhe bir koşulu kabul etmesi kanımızca yorum denetimi yoluyla çözülemez. Yorum yalnızca bu bireysel anlaşmanın oluşup oluşmadığ 1 konusunda önem taşıyabilir ki bu konuda bir şüphe bulunmuyorsa, yani aleyhe olan bireysel anlaşma geçerliyse artık başvurulabilecek tek yol içerik denetimidir.

mevcudiyetinin ispatına dair açıklamalar için bkz. ATAMULU, s. 117 vd.; ATAMER, (2012), s. $20 \mathrm{vd}$. Bireysel anlaşmaya dayanan tarafın, bunu ispat yükü altında olduğu hususunda bkz. KRAMER/PROBST/PERRIG, N 246; ATAMER, (2012), s. 24.

18 KRAMER/SCHMIDLIN, Art. 1 N 219; KRAMER/PROBST/PERRIG, N 244, 261; JÄGGI/ GAUCH, Art. 18 N 471; ATAMULU, s. 126-127.

19 LÖRTSCHER, s. 111; SCHÖNENBERGER/JÄGGI, Art. 1 N 492. Tarafların bazı sözleşme hükümlerini bireysel müzakere etmekle ilgili genel işlem koşullarını dışlamış olacağ yönünde bkz. BÜHRER, N 30.

20 KRAMER/PROBST, N 241; SCHWENZER, N 45.09; SCHULER, s. 120-121; OĞUZ, s. 83; ATAMER, (2012), s. 38.

21 LOCHER, s. 60; KOCAYUSUFPAŞAOĞLU, § 23 N 22; ATAMER, (2001), s. 124-125; ATAMER, (2012), s. 39; ATAMULU, s. 110-111.

22 ATAMER, (2001), s. 127.

23 LOCHER, s. 29.

Ankara Hacı Bayram Veli Üniversitesi Hukuk Fakültesi Dergisi C. XXIII, Y. 2019, Sa. 3201 


\section{Genel İşlem Koşulunun Anlamına İlişkin Uyuşmazlık Bulunmalı}

Genel işlem koşulunun yorumlanmasının gündeme gelebilmesi için sözleşme parçası hâline gelen genel işlem koşulunun anlamı üzerinde tarafların bir uyuşmazlığa düşmüş olması gerekir ${ }^{24}$. Şüphesiz ilgili genel işlem koşulu farklı anlamlara gelmedikçe veya taraflar bunlara başka mana yüklemedikçe bir yorum uyuşmazlığından bahsedilemez ${ }^{25}$. Bir başka ifadeyle, genel işlem koşulu açıkça tek bir anlama geliyorsa o zaman yorum uyuşmazlığından bahsedilemeyeceği için birden çok anlama gelme kuralının uygulanması da gündeme gelmez ${ }^{26}$. Bu bakımdan genel işlem koşullarının ifade tarzı, içeriği veya kapsamı hususunda bir uyuşmazlık bulunmalıdır ${ }^{27}$.

Şayet taraflar genel işlem koşullarının yorumu hususunda görüş ayrılığına düşmemişlerse artık genel işlem koşullarının yorumuna başvurulamaz. Bununla birlikte söz konusu genel işlem koşullarına, içerik denetimi aşamasında -şartları varsa- elbette müdahale edebilir.

\section{B. Yorumda Uygulanabilecek İlkeler}

\section{Yorumun Nasıl Yapılacağına İlişskin Görüşler}

\section{a. Objektif Görüş}

Objektif görüş, genel işlem koşullarını bir hukuk normu gibi değerlendirir ve genel işlem koşullarının uyuşmazlık konusu somut olayın özelliklerinden soyutlanarak nesnel bir şekilde yorumlanması gerektiğini savunur ${ }^{28}$. Zira genel

24 KRAMER/PROBST/PERRIG，N 235; KOLLER, N 23.55; ATAMULU， s. 110-111; HAVUTÇU, s. 148. Dolayısıyla yorum aşamasında genel işlem koşulunun sözleşmenin bir parçası olup olmadığı tartışması önem arz etmez. Aksine sadece genel ișlem koşulunun anlamına veya kapsamına dair taraflar arasında uyuşmazlık bulunması gerekir. Bu doğrultuda bkz. BERGER, N 962.

25 HAVUTÇU, s. 148. Zira taraflar, her ne kadar farklı anlamlara gelmeye müsait olsa da genel işlem koșuluna aynı anlamı atfetmişlerse artık TBK m. 19/I hükmü uyarınca sözleşme, tarafların koşula verdiği anlam ile kurulur. Aynı doğrultuda bkz. KOLLER, N 23.79.

26 SCHMIDT, § 305c N 46.

27 Sözleşmenin esaslı noktalarından biri üzerinde uyuşmazlık söz konusuysa irade beyanlarının gizli uyuşmazlığı nedeniyle sözleşmenin kurulmadığı ortaya çıkar. Oysaki genel işlem koşulu içeren sözleşmelerde muhatap lehine yorum yapılması sebebiyle sözleşmenin kurulmamış sayılmasının gündeme gelmeyeceği yönünde bkz. ATAMER, (2004), s. 301.

28 BASEDOW, $\$ 305 \mathrm{c} \mathrm{N} 28,33$ vd.; RUSCH, s. 203; LOCHER, s. 54; SCHWENZER, N 45.08; RAISER, s. 252-253; HAVUTÇU, s. 151. Bu bakımdan yapılacak objektif yorumun belki ilk aşamada muhatap aleyhine bir anlam doğuracağı; fakat bu olumsuz anlamın genel işlem koşulunun butlanına yol açabileceği ve bu bakımdan muhatabın lehine olabilecek en iyi 
işlem koşulları da tıpkı kanunlar gibi, çok sayıdaki farklı olaya uygulanabilecek genel bir şekilde kaleme alınır ${ }^{29}$. Objektif görüş, sözleşmenin kurulması bakımından zayıf tarafın kim olduğunun önem arz etmediğini ve genel işlem koşulları eliyle çok sayıda sözleşme kurulması amaçlandığından genel işlem koşullarının sözleşmenin karşı tarafindan bağımsız olarak yorumlanması gerektiğini savunmaktadır ${ }^{30}$. Bu çerçevede genel işlem koşullarının yorumu objektif olarak yapılmalı, dürüst ve orta zekâlı sözleşme tarafı genel işlem koşulundan ne anlayacak idiyse o anlama üstünlük tanınmalıdır ${ }^{31}$.

\section{b. Sübjektif Görüş}

İsviçre hukukunda baskın olan sübjektif görüş, genel işlem koşullarının olağan sözleşme hükümleri gibi yorumlanması gerektiğini ileri sürmektedir ${ }^{32}$. Genel bir ilkeyle ifade edilecek olursa sübjektif görüş; objektif görüşün aksine, somut olayın koşullarını yorum aşamasında dikkate almaktadır ${ }^{33}$. $\mathrm{Bu}$ bağlamda genel işlem koşullarının tıpkı kanunlar gibi yorumlanması, somut olayda sözleşmenin tarafını oluşturan muhatabın aleyhine olacağı için reddedilmelidir; zira böyle bir yorum ne sözleşme tarafının durumunu ne de somut koşulları dikkate alır ${ }^{34}$. Kaldı ki her ne kadar genel işlem koşulları

yorum hâline gelebileceği yönünde bkz. RUSCH, s. 204-205. Genel işlem koşulları bireysel olarak müzakere edilmediği için TBK m. 19/I (Art. 18/I OR) uyarınca tarafların gerçek irade beyanlarının bulunabilmesinin mümkün olmadığ 1 , bu sebeple genel işlem koşullarının normatif objektif şekilde yorumlanması gerektiği yönünde bkz. KRAMER/PROBST, Art. 1 N 241. Şayet tarafların yaptığı bireysel anlaşmalar varsa bunların doğal olarak objektif görüş çerçevesinde yorumlanmayacağ yönünde bkz. LOCHER, s. 54.

29 RAISER, s. 253; HAVUTÇU, s. 151.

30 LOCHER, s. 54; HAVUTÇU, s. 150. krş. STUCKI, s. 25.

31 BASEDOW, § 305c N 33; RAISER, s. 252; STADLER, § 305c N 6. krş. STUCKI, s. 25.

32 KOLLER, N 23.79 dn. 68; GAUCH/SCHLUEP/SCHMID, N 1241; SCHÖNENBERGER/ JÄGGI, Art. 1 N 490; JÄGGI/GAUCH, Art. 18 N 466; ZELLER § 11 N 132; AUER, s. 10; KRAMER/SCHMIDLIN, Art. 1 N 218-219, Art. 18 N 60; BAUER, s. 48; KOCAYUSUFPAŞAOĞLU, § 23 N 22; KUT, Art. 1 N 60, Art. 18 N 20; KAPLAN, (2013), s. 75; ATAMER, (2001), s. 133-134; BGE 135 III 413 E. 3.2; BGE 135 III 225 E. 1.3; BGE 135 III 6 E. 2; BGE 117 II 621 E. 6c. Nitekim İsviçre Federal Mahkemesi'nin de müstakar içtihatları ile genel işlem koşullarının akdî bir karakteri haiz olduğunu, bu sebeple yorumlarının da normal sözleşmenin yorumu gibi yapılmasını kabul ettiği yönünde bkz. WIEGAND, s. 337.

33 LÖRTSCHER, s. 109; ATAMER, (2001), s. 133-134. Muhatap genel işlem koşullarını global kabul etmiş olsa da sübjektif görüş̧e göre yorum yapılması ve muhatabın içinde bulunduğu koşulların dikkate alınması gerektiği yönünde bkz. SCHÖNENBERGER/JÄGGI, Art. $1 \mathrm{~N}$ 490.

34 KOLLER, N 23.79; ZELLER § 11 N 132 dn. 206; SCHMIDT, § 305c N 49; WIEGAND, 
önceden çok sayıda sözleşmede kullanılmak amacıyla kaleme alınmış olsa da bunlar artık somut bir sözleşmenin parçası hâline geldiği için bireysel olarak yorumlanmalıdır ${ }^{35}$. Bu çerçevede aynı genel işlem koşulunun, her bir somut olayın değişik şartları çerçevesinde farklı yorumlanabilmesi mümkündür ${ }^{36}$.

Sübjektif görüş uyarınca, öncelikle -tespit edilebiliyorsa- tarafların gerçek iradeleri dikkate alınır ${ }^{37}$. Gerçek iradelerin tespit edilememesi hâlinde ise güven teorisine göre tarafların farazî iradeleri esas alınır; yani dürüst, makul ve orta zekâlı sözleşme tarafinın somut olayın şartları altında anılan genel işlem koşulundan ne anlaması gerektiği belirlenmeye çalışılır ${ }^{38}$. Bu çerçevede sözleşme hükümlerinin lâfzî anlamı, sözleşmedeki yeri, taraflar arasındaki sözleşme görüşmelerinin seyri, sözleşme ile tarafların elde etmeyi bekledikleri amaçlar, tarafların menfaati ve karşı tarafın söz konusu işlem alanındaki deneyimi de dikkate alınır ${ }^{39}$.

Bununla beraber genel işlem koşullarının sübjektif görüş uyarınca yorumlanmasının, objektif görüşe göre yapılacak yorumdan sonuç itibarıyla çok farklı olmayacağı da ileri sürülmektedir. Gerçekten genel işlem koşullarının hazırlandığı sırada, somut olayın koşullarının ciddi bir etkisinin olduğu söylenemez ${ }^{40}$. Bununla birlikte genel işlem koşullarını kullanan tarafın, karşılaştığı durumlara göre genel işlem koşullarını güncellediği de göz ardi edilemez.

s. 336; GAUCH/SCHLUEP/SCHMID, N 1241; LÖRTSCHER, s. 108; KRAMER/ SCHMIDLIN, Art. 1 N 218, 220, Art. 18 N 60; SCHÖNENBERGER/JÄGGI, Art. 1 N 489490; JÄGGI/GAUCH, Art. 18 N 466-467; BAUER, s. 53; KUT, Art. 18 N 20; OĞUZ, s. 82; YELMEN, s. 116-117.

35 GAUCH/SCHLUEP/SCHMID, N 1144, 1241; KOLLER, N 23.79; SCHMIDT, § 305c N 49; BAUER, s. 48; ATAMER, (2001), s. 133-134.

36 KRAMER/PROBST/PERRIG, N 236-237.

37 ZELLER § 11 N 132; KRAMER/PROBST/PERRIG, N 237, 242; ATAMER, (2001), s. 130131.

38 KRAMER/PROBST/PERRIG, N 238; AUER, s. 10; GAUCH/SCHLUEP/SCHMID, N 1200-1201, 1241; KRAMER/SCHMIDLIN, Art. 1 N 218-220; KOCAYUSUFPAŞAOĞLU, $\S 23$ N 22; ATAMER, (2001), s. 130-131; KUT, Art. 1 N 60; KOLLER, N 23.19-23.20; BGE 126 III 391 E. 9d; BGE 122 III 121 E. 2a; BGE 117 II 621 E. 6c.

39 KRAMER/SCHMIDLIN, Art. 1 N 220; SCHÖNENBERGER/JÄGGI, Art. 1 N 490; OĞUZ, s. 82; ATAMER, (2001), s. 130-131; OĞUZMAN/ÖZ, s. 198-199. Hâkimin sözleşmenin kurulduğu andaki durumu dikkate alarak yorum yapacağı yönünde bkz. KRAMER/ PROBST/PERRIG, N 237.

40 KRAMER/SCHMIDLIN, Art. 1 N 219; ATAMER, (2001), s. 132. Hatta bu bakımdan genel işlem koşullarının objektif olarak hükmün lafzı, sistematiği ve anlamına göre yorumlanması gerektiği yönünde bkz. KRAMER/SCHMIDLIN, Art. 1 N 219. 


\section{c. Görüsşlerin Değerlendirilmesi}

Objektif görüşe göre genel işlem koşulları yeknesak yorumlanmalıdır. Zira genel işlem koşulları, önceden hazırlanmış olduğundan somut olayın koşullarından etkilenmemiştir. $\mathrm{Bu}$ noktada söz konusu görüşe katılıyoruz. Gerçekten de genel işlem koşullarının kullanıldığı sözleşmelerde, somut olayın koşulları önemli bir tesire sahip değildir. Bununla birlikte objektif görüşün benimsenmesi, ekonomik açıdan güçlü olan ve genel işlem koşullarını kullanan tarafin menfaatlerine hizmet eder ${ }^{41}$. Bu bakımdan zayıf muhatabın, kendisine dayatılan genel işlem koşulları karşısında korunması daha makul ve mantıklı gözükmektedir ${ }^{42}$. Bir başka ifadeyle; muhatap, kabul etmek zorunda kaldığ1 genel işlem koşullarının anlamına ilişkin ortaya çıkabilecek olası uyuşmazlıklarda mümkün olduğunca korunmalıdır.

Anılan sebeplerle genel işlem koşullarını içeren sözleşmeyi sıradan bir sözleşmeden farklı olarak yorumlamaya gerek yoktur ${ }^{43}$. Her ne kadar bahis konusu koşullar önceden hazırlanmış olsa da karşı tarafin kabul beyanı olmadıkça hukukî açıdan hiçbir değer ifade etmezler. Bu çerçevede, muhtemel yorum uyuşmazlıklarının çözümü olağan bir sözleşmeden farklılık arz etmez. Özetle, genel işlem koşullarının yorumlanmasının sübjektif metoda göre yapılması kanaatimizce daha uygundur. Taraflar arasında yorum uyuşmazlığ1 çıkarsa öncelikle tarafların ortak gerçek iradeleri araştırılmalı ve buna göre sorun çözülmelidir. Tarafların gerçek iradeleri tespit edilemezse güven teorisine göre irade beyanlarını yorumlamak gerekir.

\section{Güven Teorisi}

Sözleşmelerin yorumunda kullanılan ilkeler, genel işlem koşulu içeren sözleşmelerin yorumunda aynı şekilde kullanılabilir ${ }^{44}$. Sözleşmelerin yorumlanmasında öncelikle tarafların ortak gerçek iradeleri esas alınır ${ }^{45}$.

${ }_{41}$ OĞUZ, s. 82; ATAMER, (2001), s. 133.

42 KOLLER, N 23.79.

43 BGE 135 III 225 E. 1.3; BGE 135 III 6 E. 2; BGE 117 II 621 E. 6c; KOLLER, N 23.79.

44 HUGUENIN/MEISE, Art. 19-20 N 27; KRAMER/PROBST/PERRIG, N 103, 236; JÄGGI/ GAUCH, Art. 18 N 464; KRAMER/SCHMIDLIN, Art. 1 N 218; TERCIER/PICHONNAZ/ DEVELIOĞLUU, N 877; AUER, s. 10; KOLLER, N 23.79; SCHWENZER, N 45.08; HUGUENIN, § 6 N 627; GAUCH/SCHLUEP/SCHMID, N 1144; BÜHRER, N 28; BASEDOW, § 305c N 28; STUCKI, s. 25; ZELLER, § 11 N 156, 279; ATAMER, (2001), s. 133-134; OĞUZ, s. 82; KAPLAN, (2013), s. 75; KAPLAN, (1991), s. 55; BGE 133 III 681 E. 3.3; BGE 133 III 610 E. 2.2; BGE 122 III 121 E. 2a. krş. WIEGAND, s. 333-334.

45 BGE 135 III 413 E. 3.2; BGE 133 III 610 E. 2.2; BGE 115 II 268 E. 5a; BAUER, s. 49; AUER, s. 10. 
Ancak tarafların ortak gerçek iradelerinin tespit edilememesi hâlinde ise yorum, güven teorisine (Vertrauensprinzip) göre yapılı4 ${ }^{46}$. Bu bağlamda; sözleşmelerin yorumlanmasında kabul gören güven teorisinden, genel işlem koşulu içeren sözleşmelerin yorumunda da yararlanılabilir ${ }^{47}$. Aşağıda izah edildiği üzere genel işlem koşullarının yorumunda öncelikle güven teorisinin kullanılması ve buna rağmen yorum uyuşmazlığı giderilemezse birden çok anlama gelme kuralına başvurulması gerekir.

\section{Birden Çok Anlama Gelme Kuralı (Unklarheitenregel, Unklarheitsregel)}

\section{a. Kavram Sorunu}

TBK m. 23 hükmü, genel işlem koşulu "açık ve anlaşılır değilse veya birden çok anlama geliyorsa" şeklinde bir ifade kullanmışsa da bu başlık altında sadece genel işlem koşulunun birden çok anlama gelmesi hâli ele alınmıştır. Esasen "birden çok anlama gelme kuralı" olarak ifade ettiğimiz bu husus, Alman hukukunda "Unklarheitenregel" ve "Unklarheitsregel" şekillerinde anılmakta olup tam karş1lığ " "açık olmama kuralı" şeklindedir ${ }^{48}$. Anılan kuralın, "açık olmama kuralı" şeklinde anılması TBK m. 23 hükmünün düzenlediği, genel işlem koşulunun "açık ve anlaşılır olmaması" hâlini çağrıştırmakta olup yanlış anlaşılmaya müsaittir. Bu sebeple, Alman hukukunda kullanılan "açık olmama kuralının" karşılığı olarak "birden çok anlama gelme kuralı" ifadesi tercih edilmiştir. Bu çerçevede "açık ve anlaşıllır olmama" ifadesi ise aşağıda sadece genel işlem koşuluna hiçbir anlam yüklenemeyen hâllere hasredilmiştir.

46 BGE 135 III 413 E. 3.2; BGE 133 III 610 E. 2.2; BGE 115 II 268 E. 5a; KOLLER, N 23.55; BAUER, s. 49; AUER, s. 10; JÄGGI/GAUCH, Art. 18 N 464; EREN, s. 154 vd.; OĞUZMAN/ÖZ, s. 198. krş. KRAMER/ SCHMIDLIN, Art. 1 N 109; AYDOĞDU, (2018), m. 23 N 2, N 3 dn. 1096. Güven teorisine dair kapsamlı açıklamalar için bkz. EREN, s. 152 vd.; OĞUZMAN/ÖZ, s. 70 vd.

47 BÜHRER, N 28; KOLLER, N 23.55; OĞUZ, s. 90; AYDOĞDU, (2014), s. 116; KAPLAN, (1991), s. 55; AKÇAAL, s. 60. Sözleşme taraflarının, genel işlem koşullarını aralarındaki sözleşmeye dâhil etmeye ilişkin yaptıkları sözleşmenin (Einbeziehungsvertrag) yorumlanmasına dair açıklamalar için bkz. SCHULER, s. 68-83.

48 KRAMER/PROBST/PERRIG, N 253; HUGUENIN, § 6 N 629; KUT, Art. 1 N 61; RAISER, s. 262, 264. Aynı anlama gelmek üzere "belirsizlik ilkesi" kavramının kullanımı için bkz. ATAMER, (2001), s. 134 vd.; ATAMER, (2004), s. 300 vd.; ATAMER, (2012), s. 35 vd. 


\section{b. Kökeni ve Karşılaştırmalı Hukuktaki Durum}

Birden çok anlama gelme kuralının kökeni, Roma hukukundaki "interpretatio contra proferentem", "ambiguitas contra stipulatorem est" ve "in dubio contra stipulatorem" ilkelerine dayanmaktadır"49. Genel işlem koşulları henüz hukuk sahnesine çıkmamış olduğu için anılan ilkeler; Roma hukukunda sözleşmeler için geçerli genel prensipler olarak kabul görmüşlerdir ${ }^{50}$.

Türk kanun koyucusunun, örnek aldığ $§ \quad 305 \mathrm{c} / \mathrm{II}$ BGB hükmünün temelini, "Unklarheitenregel" kenar başlı̆̆ına sahip ve "Zweifel bei der Auslegung Allgemeiner Geschäftsbedingungen gehen zu Lasten des Verwenders." şeklindeki § 5 AGBG hükmü oluşturmaktadır ${ }^{51}$. Nitekim 2002 y1lı itibarıyla yürürlüğe giren $\S$ 305c/II BGB, bahsedilen hükmü hiçbir değişiklik yapmaksızın tekrarlamıştır". Anılan hüküm "Genel işlem koşullarının yorumlanmasındaki şüphe, genel işlem koşullarını kullananın aleyhine yorumlanır." şeklinde tercüme edilebilir. Keza çeşitli yabancı hukuk düzenlerinde de benzer hükümler mevcuttur ${ }^{53}$. Aynı esas, Art. 4.6 Unidroit ve Art. 5:103 PECL düzenlemelerinde "contra proferentem rule" ad1 altında, Art. 65 CESL'de ise "interpretation against supplier of a contract term" kenar başlı̆̆ 1 ile düzenlenmiştir ${ }^{54}$.

49 DIGESTA, 34, 5, 26; DIGESTA, 45, 1, 38, 18; KRAMER/PROBST/PERRIG, N 254; JÄGGI/ GAUCH, Art. 18 N 451; AUER, s. 10 dn. 3; HUGUENIN, § 6 N 629; RAISER, s. 262, 264; GAUCH/SCHLUEP/SCHMID, N 1231; KRAMER/PROBST, N 241 dn. 233; TERCIER/ PICHONNAZ/DEVELIOĞLU, N 877; OĞUZ, s. 98; KOCAYUSUFPAŞAOĞLU, § $23 \mathrm{~N}$ 22; KRAMER/SCHMIDLIN, Art. 1 N 109, 221; AYDOĞDU, (2014), s. 117; AYDOĞDU, (2018), m. 23 N 5; ATAMER, (2004), s. 300 dn. 36; AKÇAAL, s. 59; YELMEN, s. 121. TBK m. 23 hükmünün gerekçesi bu bakımdan "nemo aiditur propriam turpitudinem allegans" ilkesini de zikretmektedir. Aynı yönde bkz. YELMEN, s. 120-121.

50 SCHMIDT, § 305c N 42.

51 BASEDOW, § 305c N 28; LOCHER, s. 59; KRAMER/SCHMIDLIN, Art. 1 N 109; OĞUZ, s. 98.

52 BASEDOW, § 305c N 28; KRAMER/PROBST/PERRIG, N 103 dn. 270; STUCKI, s. 26 dn. 137-140. Anılan kuralın ticarî işlemlerde de uygulanabileceği yönünde bkz. BASEDOW, § $305 \mathrm{c}$ N 28; STADLER, § 305c N 1.

53 KRAMER/PROBST/PERRIG, N 253 dn. 1120; KRAMER/SCHMIDLIN, Art. 1 N 109; BASEDOW, § 305c N 29; KRAMER/PROBST, N 241 dn. 233; SCHÖNENBERGER/ JÄGGI, Art. 1 N 489; STUCKI, s. 26 dn. 137-140; BAUER, s. 51 dn. 84; AUER, s. 11; ATAMER, (2004), s. 300 dn. 36. Bu bakımdan Art. 1370 CCI, Art. 1162 CCF, § 915 AGBG, Art. 1288 CCS, § 266-268 ALR ve Art. 5 RL 93/13/EWG düzenlemeleri örnek gösterilebilir.

54 GAUCH/SCHLUEP/SCHMID, N 1232; KRAMER/PROBST/PERRIG, N 253; STUCKI, s. 27. CISG'de açık düzenleme bulunmadığı ve meselenin Art. 8 CISG hükmü çerçevesinde çözümleneceği yönünde bkz. STUCKI, s. 27. 
Türk hukuku bakımından temel düzenleme hiç şüphesiz TBK m. 23 hükmü olmakla birlikte Yargıtay'ın anılan kuralı eski tarihli kararlarında zikrettiğine de rastlanmaktadır ${ }^{55}$. Keza TKHK m. 5/IV hükmü ile Tüketici Sözleşmelerindeki Haksız Şartlar Hakkında Yönetmelik ${ }^{56}$ m. 6/III hükmü de benzer düzenlemeler içermektedir. Her ne kadar TBK m. 23 hükmü, sadece genel işlem koşullarının kullanılması hâlinde uygulanabilecek gibi bir intiba uyandırsa da "beyanı kaleme alan aleyhine yorum kuralı" şeklinde adlandırılan ilkenin, dürüstlük kuralı ve güven prensibinden türetilmesi nedeniyle ${ }^{57}$ genel işlem koşulu içermeyen sözleşmelerde de kullanılabileceği haklı olarak ifade edilmektedir ${ }^{58}$. Esasen bu tutum, yukarıda ifade edilmiş Roma hukuku ilkelerinin tüm sözleşmeler için uygulanma kabiliyetine sahip olmasıyla da örtüşmektedir.

İsviçre hukukunda birden çok anlama gelme kurall, sadece sigorta sözleşmeleri bakımından Art. 33 VVG hükmünde açıkça düzenlenmiştir ${ }^{59}$. Bununla birlikte genel işlem koşulu içermeyen diğer sözleşmeler bakımından da birden çok anlama gelme kuralının uygulanabileceği hem öğretide hem içtihatlarda kabul görmektedir ${ }^{60}$.

\section{c. Uygulanması}

Genel işlem koşulunun anlamına ilişkin bir tereddüt yaşanırsa genel işlem koşulu, kullananın aleyhine ve muhatabın lehine olacak şekilde yorumlanır ${ }^{61}$.

55 Yarg. 3. HD, T. 02.06.1998, E.1998/4263, K. 1998/6098: "Gerek ülkemizde, gerek Alman ve İsviçre Mahkeme İçtihatları ile bilimsel ögretisinde, ... açık olmayan kayıtların metni kaleme alanın aleyhine yorumlanacağl, ... ilkeleri geliştirilmiş ve uygulanmıştır."

56 Anılan Yönetmelik, 17.06.2014 tarih ve 29033 say1lı Resmî Gazete' de yayımlanmıştır.

57 STUCKI, s. 26; AUER, s. 10-11; AYDOĞDU, (2018), m. 23 N 5. TBK m. 23 hükmünün gerekçesi de aynı doğrultudadır. Aksi yönde bkz. KRAMER/ SCHMIDLIN, Art. 1 N 109; LÖRTSCHER, s. 110 dn. 18.

58 EREN, s. 494-495; OĞUZMAN/ÖZ, s. 171, 199-200.

59 GAUCH/SCHLUEP/SCHMID, N 1231; KRAMER/PROBST/PERRIG, N 253; HUGUENIN, § 6 N 630; SCHWENZER, N 45.10; GUHL/KOLLER/SCHNYDER/ DRUEY, § 13 N 52; STUCKI, s. 26; BAUER, s. 51 dn. 84; KOLLER, N 23.53; BGE 124 III 155 E. 1a; BGE 133 III 61 E. 2.2.2; BGE 115 II 269 E. $5 a$.

${ }^{60}$ HUGUENIN, §6 N 630; KOLLER, N 23.53; JÄGGI/GAUCH, Art. 18 N 459; SCHWENZER, N 45.10; STUCKI, s. 26. Aksi görüşte bkz. AUER, s. 10.

${ }^{61}$ GAUCH/SCHLUEP/SCHMID, N 1144, 1231; KRAMER/SCHMIDLIN, Art. 18 N 61; KUT, Art. 18 N 17; SCHÖNENBERGER/JÄGGI, Art. 1 N 489; JÄGGI/GAUCH, Art. 18 N 459; STUCKI, s. 26; SCHMIDT, § 305c N 61; BERGER, N 962; BASEDOW, § 305c N 47-49; HUGUENIN, § 6 N 629; LOCHER, s. 59; SCHWENZER, N 45.10; RAISER, s. 262, 264; BAUER, s. 51; BGE 133 III 610 E. 2.2; BGE 133 III 69 E. 2.2.2.3; BGE 132 
Zira genel işlem koşullarını kullananın, yani bunları kaleme alan veya hazırlatan kişinin, sahip olduğu tek taraflı belirleme imkânı sebebiyle genel işlem koşullarını hiçbir anlam muğlaklığına yer vermeyecek özenli bir şekilde düzenlemesi gerekir ${ }^{62}$. Karşı bir bakış açısı ile de muhatabın, hazırlanmasında ve kullanılmasında hiçbir dahlinin bulunmadığı genel işlem koşullarının müphem olması sebebiyle mağdur edilmemesi gerektiği söylenebilir ${ }^{63}$.

Birden çok anlama gelme kuralının uygulanabilmesi için hangi anlama geldiği tartışmalı olan sözleşme hükmünün birden çok, yani asgarî iki farklı

III 267 E. 2.2; BGE 124 III 158-159 E. 1b; BGE 122 V 146 E. 4c; BGE 122 III 121 E. 2a; BGE 117 II 621-622 E. 6c; BGE 115 II 268 E. 5a; BGer 9C_95/2011 E. 4.2.2. TBK m. 23 hükmündeki "karşı tarafin lehine" ibaresinin tek başına yeterli olması sebebiyle "düzenleyenin aleyhine" ifadesinin fuzulî olduğu yönünde bkz. AYDOĞDU, (2014), s. 116. Birden çok anlama gelme kuralının, yorum kurumu ile herhangi bir ilgisinin bulunmadığ yönünde bkz. LÖRTSCHER, s. 110. Yazar'a göre; yorumun amacı tarafların iradeleri tespit edilerek belirsizliğin giderilmesiyken birden çok anlama gelme kuralında güven teorisinden yararlanılmaksızın doğrudan, kullananın aleyhine olan anlam esas alınmaktadır. Yorumun amacının sözleşme hükmünün içeriğini tespit etmek olduğu, bu bakımdan tarafların varmış oldukları anlaşmanın içeriğini değerlendirmenin yorumla bağdaşmayacağı yönünde bkz. LÖRTSCHER, s. 111. Birden çok anlama gelme kuralı ile sözleşmenin tamamlayıcı yorumu arasında çelişki bulunmadığı yönünde bkz. BASEDOW, § 305c N 64. Zira Yazar'a göre; birden çok anlama gelme kuralı mevcut genel işlem koşulunun yorumunda kullanılırken tamamlayıcı yorum, genel işlem koşulu bulunmaması sebebiyle sözleşmede meydana gelen boşluğu doldurmayı amaçlar.

62 KOLLER, N 23.55-23.56; BASEDOW, § 305c N 43; SCHWENZER, N 45.10; JÄGGI/ GAUCH, Art. 18 N 459; GAUCH/SCHLUEP/SCHMID, N 1231; KRAMER/PROBST/ PERRIG, N 253, 255; SCHMIDT, § 305c N 42; SCHÖNENBERGER/JÄGGI, Art. 1 N 489; HUGUENIN, § 6 N 629; STUCKI, s. 26; EREN, s. 223, 494; ATAMER, (2001), s. 135; ATAMER, (2004), s. 300; ATAMER, (2012), s. 36; HAVUTÇU, s. 152; YELMEN, s. 121; BGE 87 II 242 E. 3; BGE 92 II 348 E. 1c. Keza TBK m. 23 hükmünün gerekçesinde de ayn1 esas vurgulanmıştır. Birden çok anlama gelme kuralının çok sınırlı olarak uygulanabileceği; zira genel işlem koşullarını kullananın her türlü tereddüdü önleyecek şekilde genel işlem koşullarını kaleme alacağı yönünde bkz. AYDOĞDU, (2014), s. 116; AYDOĞDU, (2018), m. $23 \mathrm{~N} 1$.

63 SCHWENZER, N 45.10; KRAMER/SCHMIDLIN, Art. 1 N 109; LOCHER, s. 59-60; KOLLER, N 23.55-23.56; ATAMER, (2001), s. 136, 138. Dürüstlük kuralına göre muhatabın, genel işlem koşulunun içerdiği uzun ve kapsamlı düzenlemeleri tamamen incelemesinin ve anlayabilmesinin beklenemeyeceği; bu sebeple genel işlem koşulunun objektif olarak birden çok anlama gelmesi hâlinde muhatabın bu durumu bilmesi ve buna sadece tek bir anlam atfetmesi gerektiği iddiasının dürüstlük kuralına aykırı olması sebebiyle dinlenemeyeceği ve daha ziyade lafzî yorum ile yetinileceği yönünde bkz. KOLLER, N 23.55. Birden çok anlama gelme kuralının esasen genel işlem koşulu içeren sigorta sözleşmelerinde sigorta ettirenin haklı menfaatini himaye etmek için kullanıldığ yönünde bkz. GAUCH/SCHLUEP/ SCHMID, N 1144; KRAMER/SCHMIDLIN, Art. 1 N 109; TERCIER/PICHONNAZ/ DEVELIOĞLU, N 951; BGE 138 III 413 E. 3.1; BGE 133 III 682 E. 3.3. 
anlam çıkarmaya elverişli olması gerekir ${ }^{64}$. Üzerinde yorum uyuşmazlığ çıkan genel işlem koşulunun lâfzî anlamının yanı sıra sözleşmenin bütünü içindeki yeri dikkate alınınca da varılabilecek birden çok anlamdan hangisini kastettiği anlaşılamamalıdır. Genel işlem koşulunun birden çok anlama gelmesi durumunda bu koşulun, genel işlem koşullarını kullananın aleyhine yorumlanması gerekir ${ }^{65}$. Bu bakımdan söz konusu iki veya daha fazla anlamdan birinin, genel işlem koşulunu kullanan tarafin daha aleyhine olması gerekir ${ }^{66}$.

${ }^{64}$ STADLER, § 305c N 6; SCHÖNENBERGER/JÄGGI, Art. 1 N 489; KOLLER, N 23.53, 23.55; BAUER, s. 50; JÄGGI/GAUCH, Art. 18 N 440, 456; HUGUENIN, § 6 N 629; BASEDOW, § 305c N 44; SCHMIDT, § 305c N 60; KRAMER/PROBST/PERRIG, N 103 dn. 270, N 257; LOCHER, s. 60; OG̈UZ, s. 94; EREN, s. 494; GAUCH/SCHLUEP/ SCHMID, N 1231; HAVUTÇU, s. 151-152; AYDOĞDU, (2014), s. 117; AYDOĞDU, (2018), m. 23 N 3; KAPLAN, (1991), s. 70. Genel işlem koşuluna verilen birden çok anlamın tespiti için öncelikle tarafların gerçek iradeleri irdelenmeli; eğer gerçek iradeler tespit edilemezse o zaman dürüstlük kuralına göre, yani objektif bir değerlendirmeyle genel işlem koşuluna verilebilecek en az iki farklı anlam belirlenmelidir. Bu noktada tarafların ilgili genel işlem koşuluna farklı anlamlar atfetmeleri nedeniyle bir irade uyuşmazlığının söz konusu olduğu; ancak muhatap için lehe anlam esas alınarak genel işlem koşulunun geçerliliğinin sağlanacağı yönünde bkz. KOLLER, N 23.53.

65 SCHWENZER, N 45.10; KRAMER/SCHMIDLIN, Art. 1 N 109, 221; KRAMER/PROBST/ PERRIG, N 260; KELLER, s. 321; GAUCH/SCHLUEP/SCHMID, N 1231 vd.; BERGER, N 962; HUGUENIN, § 6 N 629; KUT, Art. 18 N 17; RAISER, s. 262, 264; TERCIER/ PICHONNAZ/DEVELİOĞLU, N 877; KAPLAN, (1991), s. 56, 58; BAUER, s. 51; KOCAYUSUFPAŞAOĞLU, § 23 N 22; BGE 133 III 610 E. 2.2; BGE 133 III 69 E. 2.2.2.3; BGE 132 III 267 E. 2.2; BGE 124 III 158-159 E. 1b; BGE 122 III 121 E. 2a; BGE 113 II 52 E. 1b; BGE 110 II 146 E. 2b; BGE 97 II 74 E. 3. Genel işlem koşulunun taraflarca farklı anlamlandırılması hâlinde irade uyuşmazlığı nedeniyle anılan genel işlem koşulunun batıl olması gerektiği; ancak genel işlem koşullarını kullananın bunların açık bir şekilde kaleme alınmasından da sorumlu olması nedeniyle butlan sonucunun uygulanmadığı yönünde bkz. BASEDOW, § 305c N 42-43. Hatta mahkemelerin sigorta sözleşmeleri bakımından "in dubio contra assicuratorem" ilkesini uyguladığı yönünde bkz. KELLER, s. 321.

66 JÄGGI/GAUCH, Art. 18 N 456; KAPLAN, (2013), s. 76. Standart sözleşme hükmünün birden çok anlama gelmesine ilişkin, “Avrupa" ifadesinin Türkiye'nin sadece Trakya topraklarını mı, yoksa Anadolu'yu da mı kapsadığı yönündeki örnek için bkz. ATAMER, (2001), s. 135. Birden çok anlama gelmeye müsait olan "Avrupa" ibaresi, muhatabın (sigorta ettirenin) lehine yorumlanmış ve Anadolu da "Avrupa" içerisinde değerlendirilmiştir. Eğer genel işlem koşulundan çıkarılabilecek anlamlardan hangisinin muhatap için daha olumlu olduğu açıklığa kavuşturulamazsa ilgili genel işlem koşulunun geçersiz olması ve yerine kanundaki tamamlayıcı hükümlerin uygulanması gerektiği yönünde bkz. LOCHER, s. 60-61. İsviçre Federal Mahkemesi çeşitli kararlarında birden çok anlama gelme kuralını uygulamıştır. Örneğin; BGE 116 II 190-191 E. 2b kararında, "Drogen" kelimesinin kapsamına "sigara"nın girmeyeceğine hükmetmiştir. BGE 85 II 348-349 E. 1b kararında "Operation" kavramının "teşhis"i kapsamayacağını belirterek muhatap lehine yorum yapmıştır. Aynı doğrultuda bkz. BAUER, s. 52. İsviçre Federal Mahkemesi BGE 82 II 452-453 E. 2 kararında ise "Einladung" kavramının sadece yükleme anlamına gelmediğini, anılan kavramın geniş anlaşılması gerektiğini belirtmiştir. Aynı doğrultuda bkz. BAUER, s. $51-52$. 
Zira olası farklı anlamların, genel işlem koşullarını kullanan taraf için aynı değerde olması hâlinde aleyhe bir uygulamadan da bahsedilemez. Keza birden çok sayıda farklı anlam olmazsa bunlardan genel işlem koşulunu kullananın aleyhine olanının seçilebilmesi de mümkün olamaz ${ }^{67}$. Bu noktada genel işlem koşuluna verilecek anlamın, -varsa- mümkün mertebe ilgili tamamlayıcı hükmün anlamına yakın olması ve muhatabın tamamlayıcı kanun hükmünün öngördügünden daha olumsuz bir konuma yerleştirilmemesi gerektiği de ileri sürülmektedir ${ }^{68}$. Bununla birlikte hangi anlam esas alınırsa alınsın ilgili genel işlem koşuluna içerik denetimi aşamasında müdahale edilecek ise artık yorum ile uğraşmaya gerek olmadığ 1 da belirtilmektedir ${ }^{69}$.

Birden çok anlama gelme kuralı, sadece bir genel işlem koşulunun objektif olarak birden fazla anlama gelmesi hâlinde uygulanmaz. Keza aynı sözleşmede yer alan birden çok genel işlem koşulu, belirli bir hususta birbirlerinden farklı düzenlemeler içerebilit ${ }^{70}$. Böyle bir durumda da, birden çok anlama gelme kuralının temelinde yatan mantık çerçevesinde, söz konusu birden çok genel işlem koşulundan muhatabın lehine olan anlama üstünlük tanınmalidir ${ }^{71}$.

Birden çok anlama gelme kuralı, sonuç olarak ilgili genel işlem koşulunun geçersizliğine yol açamaz ${ }^{72}$. Bu bakımdan genel işlem koşuluna, muhatap için en lehe olan; fakat aynı zamanda da geçerliliğini koruyan anlam yüklenir ${ }^{73}$. Böylece genel işlem koşullarının içerdiği bazı katı düzenlemeler yumuşatılarak muhatabın lehine olacak bir hâle dönüştürülebilir ${ }^{74}$. Birden çok anlama gelme kuralı, hiç şüphesiz terazinin diğer kefesinde bulunan kullananın zararınadır.

67 KUT, Art. 1 N 61; KRAMER/SCHMIDLIN, Art. 1 N 221; GUHL/KOLLER/SCHNYDER/ DRUEY, § 13 N 52; KRAMER/PROBST/PERRIG, N 257; KRAMER/PROBST, N 241; KELLER, s. 321-322; SCHWENZER, N 45.10; HUGUENIN, § 6 N 629; JÄGGI/GAUCH, Art. 18 N 457; BASEDOW, § 305c N 44, 48, 49; STADLER, § 305c N 7; LOCHER, s. 60; WIEGAND, s. 338; RAISER, s. 101, 262, 264; SCHMIDT, § 305c N 42, 60-61; ATAMER, (2001), s. 134; BGE 133 III 610 E 2.2; BGE 122 III 121 E. 2a; BGer 5C.271/2004 E. 2.

68 KRAMER/PROBST/PERRIG, N 268; KRAMER/PROBST, N 241; BGE 133 III 610 E. 2.2.

69 ATAMER, (2001), s. 136-137; ATAMER, (2004), s. 302.

70 Örnek için bkz. AYDOĞDU, (2018), m. 23 N 16.

71 AYDOĞDU, (2018), m. 23 N 16.

72 KRAMER/PROBST/PERRIG, N 260.

73 KRAMER/PROBST/PERRIG, N 260.

74 RAISER, s. 101. krş. AUER, s. 22-23.

Ankara Hacı Bayram Veli Üniversitesi Hukuk Fakültesi Dergisi C. XXIII, Y. 2019, Sa. 3211 


\section{d. Muhatap İçin En Olumsuz Anlamın Esas Alınmasını Savunan Görüş}

Birden çok anlama gelme kuralı, muhatap için en lehe anlamın esas alınması gerektiğini açıkça öngörmüştür. Buna rağmen, yorum yoluyla elde edilen anlamlardan muhatap için en olumsuzunun esas alınması ve böylece genel işlem koşulunun geçersizliğinin sağlanması yoluyla muhatabın daha da lehine bir durumun tesis edilebileceği ileri sürülmektedir ${ }^{75}$. Bu bakımdan yorum aşamasında, genel işlem koşuluna verilebilecek olası anlamlar neticesinde içerik denetiminin nasıl sonuçlanabileceğinin dikkate alınması gerektiği savunulmaktadır ${ }^{76}$. Bir başka ifadeyle anılan görüş; genel işlem koşuluna muhatap için en olumsuz anlamın yüklenmesini ve böylece genel işlem koşulunun içerik denetimi aşamasına takılarak bunun yerine kanunun tamamlayıcı hükmünün uygulanması yoluyla muhatap için daha olumlu bir sonucun elde edilmesini amaçlamaktadır.

Söz konusu görüş; somut olayın koşullarını dikkate alan sübjektif görüş çerçevesinde genel işlem koşullarının yorumlanması yaklaşımına uygun düşmemesi ve böyle bir müdahalenin yorum denetiminin kapsamını aşarak içerik denetimine taştığ 1 gerekçesiyle eleştirilmektedir ${ }^{77}$.

\section{e. Talî Niteliği}

Birden çok anlama gelme kuralı, sözleşmenin yorumunda kullanılacak mutad yöntemler ile bir sonuç alınamaması hâlinde uygulama alanı bulabilen ikincil bir yorum kuralıdır ${ }^{78}$. Şu hâlde; öncelikle, sözleşmeler için geçerli yorum yöntemleri ile anlamı şüpheli olan genel işlem koşulu anlamlandırılmaya çalış1lmalı ve bunlar eliyle bir sonuca ulaşılamazsa birden çok anlama gelme kuralına başvurulmalıdır. Nitekim İsviçre Federal Mahkemesi de kararlarında

75 RUSCH, s. 204. Keza genel işlem koşulunun birden çok anlama gelmesi hâlinde muhatabın en aleyhine yorumun benimsenmesi anlayışı reddedilirse de yorum ile içerik denetiminin birbirine karışacağ1 yönünde bkz. RUSCH, s. 205.

76 ATAMER, (2004), s. 301-302; ATAMER, (2012), s. 37-38.

77 KRAMER/PROBST/PERRIG, N 261. Birden çok anlama gelme kuralının, gizli bir içerik kontrolü aracı olarak kullanılmaması gerektiği yönünde bkz. LOCHER, s. 60; HAVUTÇU, S. 151.

78 BASEDOW, § 305c N 44; KRAMER/SCHMIDLIN, Art. 1 N 109; GAUCH/SCHLUEP/ SCHMID, N 1232; SCHÖNENBERGER/JÄGGI, Art. 1 N 489; JÄGGI/GAUCH, Art. 18 N 452; KRAMER/PROBST/PERRIG, N 244, 257, 265; RAISER, s. 262; KRAMER/ PROBST, N 241; LOCHER, s. 60; BAUER, s. 50; ATAMER, (2001), s. 136, 138; ATAMER, (2012), s. 37; BGE 109 II 219 E. 2b. krş. AYDOĞDU, (2018), m. 23 N 10. 
birden çok anlama gelme kuralının talî niteliğini ve son çare (ultima ratio) olduğunu vurgulamaktadır ${ }^{79}$. Bu bakımdan birden çok anlama gelme kuralının uygulanabilmesi için; genel işlem koşulunun birden çok anlama gelmesi tek başına yeterli değildir, ayrıca diğer yorum vasıtalarıyla yapılan yoruma rağmen hükmün birden çok anlamdan hangisini kastettiği anlaşılamamalıdır ${ }^{80}$.

\section{f. Açık ve Anlaşılır Olmama}

TBK m. 23 hükmü; örnek aldığ $§ 305$ c/II BGB düzenlemesinden farkl1 bir içeriğe sahiptir. Her iki düzenleme de genel işlem koşulunun, birden çok anlama gelmesi hâlinde kullananın aleyhine olan anlamın esas alınacağ noktasında örtüşmektedir. Ancak TBK m. 23 hükmü ayrıca, -§ 305c/II BGB düzenlemesinden farklı olarak- genel işlem koşulunun açık ve anlaşılır olmaması hâllerinde de kullananın aleyhine yorumlanacağını düzenlemiştir.

Birden çok anlama gelme kuralında esas olan, genel işlem koşulundan birden fazla olası anlam çıkarılabilmekle birlikte, hangi anlam üzerinde tarafların iradelerinin uyuşmuş olduğunun net ve tam olarak anlaşılamamasıdır. Şu hâlde genel işlem koşulunun tek başına açık ve anlaşılır olmaması, yani neyi düzenlediğinin hiç anlaşılamadığı ve/veya bu koşula hiçbir anlam verilemediği hâllerde genel işlem koşulundan birden fazla anlamın çıkarılabilmesi de mümkün olamaz. Kısacası genel işlem koşulundan hiçbir anlam çıkarılamadığından yorum denetiminden de bahsedilemez. Bu sebeple hiçbir anlam çıkarılamayan genel işlem koşulunun, -TBK m. 23 düzenlemesinin aksine- kullananın aleyhine yorumlanabilmesi de söz konusu olamaz ${ }^{81}$. Bunun yerine; hiçbir anlam verilemeyen genel işlem koşulunun, içerik denetimi aşamasında ele alınması ve geçersiz olduğu sonucuna varılması gerekir ${ }^{82}$.

79 HUGUENIN, § 6 N 629; BGE 122 III 124 E. 2d; BGE 100 II 153 E. 4c; BGE 99 II 292 E. 5; BGer 5C.271/2004 E. 2. Anılan tutumun eleştirisi için bkz. LÖRTSCHER, s. 110. Yazar'a göre, birden çok anlama gelme kuralının talî olarak kullanılması reddedilmelidir. Zira hükmün bağımsız anlamı elde edilemiyorsa o zaman taraflar bağlayıcı bir anlaşma meydana getirmemişlerdir. Keza güven teorisi çerçevesinde genel işlem koşulunun birden çok anlama gelmesi söz konusuysa ve taraflar da ilgili hükme fiilen farklı anlam veriyorlarsa artık, iradeler arasında gizli uyuşmazlığın bulunduğunun ve sözleşmenin kurulmadığının kabul edilmesi gerektiği yönünde bkz. LÖRTSCHER, s. 110 dn. 18.

80 GUHL/KOLLER/SCHNYDER/DRUEY, § 13 N 52; BGE 122 III 124 E. 2 d.

81 SCHMIDT, § 305c N 60; JÄGGI/GAUCH, Art. 18 N 458; KAPLAN, (2013), s. 77; AYDOĞDU, (2014), s. 122-123; AYDOĞDU, (2018), m. 23 N 9-10, 17.

82 BASEDOW, § 305c N 47; SCHMIDT, § 305c N 60; ATAMER, (2001), s. 140-141; KELLER, s. 321; AYDOĞDU, (2014), s. 119-121; AYDOĞDU, (2018), m. 23 N 8, 12. krş. SCHMIDT, $\S 305 \mathrm{c} \mathrm{N} 61$. Hiçbir anlam elde edilemeyen genel işlem koşulunun yazılmamış sayılacağı 
Nitekim § 307/I BGB hükmü, bu durumda açık ve anlaşılır olmayan genel işlem koşulunun geçersiz olduğunu düzenlemiştir ${ }^{83}$. Anılan sebeplerle TBK m. 23 düzenlemesinin isabetli olmadığı söylenebilir ${ }^{84}$.

\section{Daralticı Yorum (restriktive Auslegung)}

Daraltıcı yorumun genel işlem koşullarının yorumlanmasında uygulanıp uygulanamayacağından önce, daraltıcı yorum ile birden çok anlama gelme kuralı arasındaki ilişkinin izah edilmesi gerekir. $\mathrm{Bu}$ noktada bir görüş; daraltıcı yorumun, birden çok anlama gelme kuralı ile ilişkili olduğunu iddia etmektedir ${ }^{85}$. Buna karşın diğer görüş ise daraltıcı yorumu, birden çok anlama gelme kuralı üst başlığ arasında bir ilişki bulunmadığını savunmaktadır ${ }^{86}$.

Birden çok anlama gelme kuralının aksine, kanun koyucu tarafından açıkça öngörülmemiş olan daraltıcı yorumun uygulanabilirliği şüphelidir. $\mathrm{Bu}$ bakımdan iki temel görüşten bahsedilebilir:

Öğretide; genel işlem koşullarını kullanan tarafın, ekonomik açıdan güçlü olmasının taraflar arasında eşitsizliğe yol açtığı belirtilerek muhatap aleyhine olan genel işlem koşullarının mümkün olduğunca dar yorumlanması ve böylece uygulama alanlarının sınırlandırılması gerektiği ileri sürülmektedir ${ }^{87}$. Nitekim İsviçre Federal Mahkemesi de bilhassa tamamlayıcı kanun hükümlerinden ayrılan genel işlem koşullarını dar yorumlamayı tercih ederek muhatabı korumayı amaçlamıştır ${ }^{88}$. Bu görüşü savunanların da kabul ettiği

yönünde bkz. SCHMIDT, § 305c N 60. 5684 sayılı Sigortac1lık Kanunu m. 11/V hükmünün bu hâlde geçersizlik sonucunu öngördüğü yönünde bkz. AYDOĞDU, (2014), s. 120; AYDOĞDU, (2018), m. 23 N 12. § 305c/II BGB hükmünün sadece yoruma ilişkin olduğu ve genel işlem koşulunun geçerliliğini etkilemeyeceği yönünde bkz. STADLER, § 305c N 7.

83 Alman hukuku bakımından açık ve anlaşılır olmayan bir genel işlem koşulunun, § 307/I BGB hükmünün ikinci cümlesindeki "Transparenzgebot" ile içerik kontrolü aşamasında geçersiz k1lınabileceği yönünde bkz. STADLER, § 305c N 7; BASEDOW, § 305c N 48. krş. AYDOĞDU, (2014), s. 118-119; AYDOĞDU, (2018), m. 23 N 6, 8-9, 17.

${ }^{84}$ Aynı yönde bkz. AYDOĞDU, (2018), m. 23 N 2, 17.

85 SCHWENZER, N 45.11.

86 LOCHER, s. 60.

87 KOLLER, N 23.80; JÄGGI/GAUCH, Art. 18 N 447; KRAMER/PROBST/PERRIG, N 244, 267; KRAMER/PROBST, N 241; KAPLAN, (1991), s. 55. krş. GAUCH/SCHLUEP/ SCHMID, N 1235.

88 BGE 115 II 479 E. 2d; BGE 130 III 689-690 E. 4.3.1; BGE 107 II 163-164 E. 6c. Ayn1 doğrultuda bkz. KRAMER/PROBST/PERRIG, N 267, 270; JÄGGI/GAUCH, Art. 18 N 447. 
üzere daraltıcı yorum yapılması, bir ölçüde gizli içerik kontrolü (verdeckte Inhaltskontrolle) yapılmas1 anlamina gelmektedir ${ }^{89}$.

Öte yandan bilhassa Alman hukukunda kabul gören karşıt görüş ise daraltıcı yorumun, gizli içerik denetimi yapılması anlamına gelmesi sebebiyle uygulanmasını reddetmektedir ${ }^{90}$. Kanun koyucu, yorum ve içerik denetimi aşamalarını birbirinden ayırmıştır ${ }^{91}$. Buna rağmen daraltıcı yorum yapılması, yorum ile içerik denetimi aşamalarının birbirine karışmasına sebebiyet verir ${ }^{92}$. Tarafların iradelerinin açık olduğu ve anlamı üzerinde yorum uyuşmazlığı bulunmayan genel işlem koşuluna farklı bir anlam yüklemeye çalışmak doğru olmaz ${ }^{93}$.

Kanaatimizce genel işlem koşullarının yorumlanmasında daraltıcı yorum yoluna başvurulabilirr ${ }^{94}$. Özellikle tamamlayıcı kanun hükümlerinden sapan genel işlem koşullarının dar yorumlanması ve anılan koşulların anlamının muhatabın lehine olacak şekilde sınırlandırılması yerinde olur ${ }^{95}$.

89 KRAMER/PROBST/PERRIG, N 270.

90 LOCHER, s. 60; BASEDOW, § 305c N 41; SCHMIDT, § 305c N 62; STADLER, § 305c N 8; ATAMER, (2001), s. 141.

91 STADLER, § 305c N 8. Keza aşırı kaydın yasal ya da caiz sınıra indirilmesi (geltungserhaltende Reduktion) kurumundan yararlanılmasının da açıkça yorum ile içerik denetimi arasında ayrım yapan kanun koyucunun iradesine aykırı olduğu yönünde bkz. BASEDOW, § 305c N 41.

92 BASEDOW, § 305c N 41; RUSCH, s. 205. Yorum denetiminin, örtülü içerik denetimi olduğu yönünde bkz. AYDOĞDU, (2018), m. 23 N 2.

93 krş. LOCHER, s. 60; ATAMER, (2001), s. 141-142.

94 JÄGGI/GAUCH, Art. 18 N 447; KOLLER, N 23.80; KAPLAN, (1991), s. 56 (Yazar, sürelere ilişkin kayıtların ise muhatabın lehine olması için geniş yorumlanmasını da önermektedir). Daraltıcı yorum ilkesinin, genel işlem koşullarında genel bir şekilde ifade edilmiş hususlara, tarafların genel bir anlam biçmediği varsayımına dayandığı yönünde bkz. KOLLER, N 23.81. Tam tersine tarafların sadece tipik bir meseleyi düzenlemek istedikleri, bu sebeple genel işlem koşulunun içerdiği genel hükmün kapsamının daraltılması gerektiği yönünde bkz. KOLLER, N 23.80-23.81; BGE 91 II 348 E. 2a. Şayet somut olayda tarafların gerçekten genel anlamı istemiş oldukları ispatlanabilirse daraltıcı yorumun uygulanamayacağı yönünde bkz. KOLLER, N 23.81. Genel işlem koşulu içermeyen sözleşmelerde de daraltıcı yorumun uygulanabileceği yönünde bkz. KOLLER, N 23.82; BGE 87 II 87 E. 3b; BGE 60 II 436 E. 4.

95 SCHWENZER, N 45.11; KOLLER, N 23.80; BGE 117 II 621 E. 6c; BGE 115 II 479 E. 2d. krş. KRAMER/PROBST/PERRIG, N 266; GAUCH/SCHLUEP/SCHMID, N 1235. Genel işlem koşullarıyla genel olarak formüle edilmiş bir sorumsuzluk kaydının, özel olarak temin edilmiş bir özelliğin bulunmaması hâlini kapsamayacağı yönünde bkz. KRAMER/ PROBST, N 241; SCHÖNNENBERGER/JÄGGI, Art. 1 N 497; KAPLAN, (1991), s. 59. Genel işlem koşullarında yer alan teknik ifadelerin, muhatabın o alanda uzman olmaması 


\section{Diğer Yorum Kuralları}

Her ne kadar TBK m. 23 hükmünde açıç̧a öngörülmüş olmasa da öğretide, genel işlem koşulları sebebiyle muhatabın maruz kaldığı olumsuz durumu, yorum yoluyla giderebilmek amaciyla çeşitli özel yorum yöntemleri geliştirilmiştir ${ }^{96}$.

Bu bağlamda örneğin; şüphe hâlinde sözleşmeyi geçersiz kılmayan, yani sözleşmeyi ayakta tutan yoruma üstünlük tanınması gerektiği belirtilmektedir ${ }^{97}$. Keza şüphe hâlinde sözleşmedeki hükümlerin de kanuna uygun bir şekilde yorumlanması ve böylece kanunda yer alan tamamlayıcı kanun hükümlerine yakın düşen bir sonuca ulaşılması gerektiği öne sürülmektedir ${ }^{98}$. Ayrıca borçlu taraf için daha makul olan anlamın (in dubio mitius) esas alınması gerektiği şeklindeki yorum kuralının, genel işlem koşulu içeren sözleşmelere de uygulanabileceği belirtilmektedir ${ }^{99}$. Benzer şekilde sözleşmenin bir bütün olduğu ve yorum yapılırken bu hususun dikkate alınması gerektiği ifade edilmektedir ${ }^{100}$.

\section{SONUÇ}

Genel işlem koşullarının yorumlanabilmesi için öncelikle; genel işlem koşulu içeren bir sözleşmenin bulunması, tarafların genel işlem koşulunun düzenlediği hususta bireysel bir anlaşma yapmamış olmaları ve genel işlem koşulunun anlamı hususunda uyuşmazlık bulunması gerekir. Genel işlem koşullarının, sübjektif görüş çerçevesinde değerlendirilmesi ve bu bakımdan yorum aşamasında olağan sözleşmelerden farklı bir muameleye tâbi tutulmaması gerekir.

Genel işlem koşulu bakımından TBK m. 23 hükmünün öngördüğü birden çok anlama gelme kuralına göre, birden çok anlama gelen genel işlem koşulunun muhatabın lehine, yani kullananın aleyhine olacak şekilde

sebebiyle günlük hayattaki anlamlarının esas alınacağı yönünde bkz. KAPLAN, (1991), s. 55.

96 KRAMER/PROBST, N 241.

97 GAUCH/SCHLUEP/SCHMID, N 1235; JÄGGI/GAUCH, Art. 18 N 441 vd. Anılan yorum ilkesinin ikincil nitelikte olduğu yönünde bkz. JÄGGI/GAUCH, Art. 18 N 446.

98 KRAMER/PROBST/PERRIG, N 266; GAUCH/SCHLUEP/SCHMID, N 1235.

99 GAUCH/SCHLUEP/SCHMID, N 1235; JÄGGI/GAUCH, Art. 18 N 448; KRAMER/ PROBST/PERRIG, N 264. krş. BGer 4A_453/2009 E. 4.3.

${ }^{100}$ KAPLAN, (1991), s. 56. 
yorumlanması gerekir. Birden çok anlama gelme kuralı, talî nitelikte olup öncelikle mutad yorum yöntemleriyle yorum uyuşmazlığının çözülmesine çalışılmalıdır. Ancak anılan yöntemlerle sonuç elde edilemezse birden çok anlama gelme kuralına başvurulabilir. Öte yandan genel işlem koşulunun açık ve anlaşılır olmaması hâlinde ise artık koşula bir anlam yüklenemeyeceği için muhatabın lehine bir yorum yapılabilmesi mümkün değildir. Burada açık ve anlaşılır olmayan genel işlem koşulunun geçersiz kabul edilmesi daha isabetli gözükmektedir. Genel işlem koşullarının yorumunda daraltıcı yorum yoluna da başvurulabilir.

\section{KAYNAKÇA}

AKÇAAL, Mehmet: "Borçlar Kanununun Genel İşlem Koşullarına Dair Hükümleri Hakkında Bir İnceleme", Gazi Üniversitesi Hukuk Fakültesi Dergisi, Y11 2014, Cilt XVIII, Sayı 1, s. 49-69.

ATAMER, Yeşim: Sözleşme Özgürlüğünün Sınırlandırılması Sorunu Çerçevesinde Genel İşlem Koşullarının Denetlenmesi, 2. Bası, Beta Basım, İstanbul, 2001. [ATAMER, (2001)]

ATAMER, Yeşim: "Genel İşlem Koşullarının Denetiminde Yeni Açılımlar", Prof. Dr. Necip Kocayusufpaşaoğlu İçin Armağan, Seçkin Yayıncılık, Ankara, 2004, s. 291-331. [ATAMER, (2004)]

ATAMER, Yeşim: "Yeni Türk Borçlar Kanunu Hükümleri Uyarınca Genel İşlem Koşullarının Denetlenmesi- TKHK m. 6 ve TTK m. 55, F. 1, (f) İle Karşılaştırmalı Olarak", Türk Hukukunda Genel İşlem Şartları ve Sempozyumu, Bankacılık Enstitüsü Yayınları, Ankara, 2012, s. 9-73. [ATAMER, (2012)]

ATAMULU, İsmail: "Genel İşlem Şartlarında Şahsî (Bireysel) Anlaşmanın Mevcudiyetini İspat Yükü”, Erciyes Üniversitesi Hukuk Fakültesi Dergisi, Y11 2018, Cilt XIII, Say1 1, s. 101-147.

AUER, Eugen: Die richterliche Korrektur von Standardverträgen, Verlag Stämpfli \& Cie, Bern, 1964.

AYDOĞDU, Murat: Türk Borçlar Hukuku'nda Genel İşlem Koşullarının ve Tüketici Hukuku'nda Haksı Şartların Denetimi, Seçkin Yayınc1lı, Ankara, 2014. [AYDOĞDU, (2014)] 
AYDOĞDU, Murat: Genel İşlem Koşulları Şerhi, Adalet Yayınevi, Ankara, 2018. [AYDOĞDU, (2018)]

BASEDOW, Jürgen: Münchener Kommentar zum Bürgerlichen Gesetzbuch, Band 2, Schuldrecht - Allgemeiner Teil, 8. Auflage, Verlag C.H. Beck, München, 2019 (Herausgeber: SÄCKER, Franz Jürgen/RIXECKER, Roland/OETKER, Hartmut/LIMPERG, Bettina).

BAUER, Walo: Der Schutz vor unbilligen Allgemeinen Geschäftsbedingungen (AGB) im schweizerischen Recht, 3. Auflage, Schulthess Polygraphischer Verlag AG, Zürich, 1981.

BERGER, Bernhard: Allgemeines Schuldrecht, 2. Auflage, Stämpfli Verlag AG, Bern, 2012.

BÜHRER, Marc P.: AGB-Kollisionen, "the battle of the forms" und weitere Probleme beim Verweis auf Allgemeine Geschäftsbedingungen, Schulthess Polygraphischer Verlag AG, Zürich, 1987.

EREN, Fikret: Borçlar Hukuku Genel Hükümler, 23. Bas1, Yetkin Yayınları, Ankara, 2018.

GAUCH, Peter/SCHLUEP, Walter R./SCHMID, Jörg: Schweizerisches Obligationenrecht Allgemeiner Teil ohne aussvertragliches Haftpflichtrecht, Band I, 10. Auflage, Schulthess Juristische Medien AG, Zürich/Basel/Genf, 2014.

GUHL，Theo/KOLLER，Alfred/SCHNYDER，Anton K./DRUEY， Jean Nicolas: Das Schweizerische Obligationenrecht mit Einschluss des Handels- und Wertpapierrechts, 9. Auflage, Schulthess Juristische Medien AG, Zürich, 2000.

HAVUTÇU, Ayşe: Açık İçerik Denetimi Yoluyla Tüketicinin Genel İşlem Koşullarına Karşı Korunması, Güncel Yayınevi, İzmir, 2003.

HUGUENIN, Claire: Obligationenrecht Allgemeiner und Besonderer Teil, 2. Auflage, Schulthess Juristische Medien AG, Zürich/Basel/Genf, 2014.

HUGUENIN, Claire/MEISE, Barbara: Basler Kommentar, Obligationenrecht I, Art. 1-529 OR, 6. Auflage, Helbing Lichtenhahn Verlag, Basel, 2015 (Herausgeber: HONSELL, Heinrich/VOGT, Nedim Peter/WIEGAND, Wolfgang). 
JÄGGI, Peter/GAUCH, Peter: Kommentar zum Schweizerischen Zivilgesetzbuch, V. Band: Obligationenrecht, Teilband V 1b, Art. 18 OR, Schulthess Polygraphischer Verlag, Zürich, 1980.

KAPLAN, İbrahim: "Banka Standart Sözleşmeleri ve Banka Genel İşlem Şartları", Banka ve Ticaret Hukuku Dergisi, Cilt XVI, Sayı 2, Y11 1991, s. 51-89. [KAPLAN, (1991)]

KAPLAN, İbrahim: Hakimin Sözleşmeye Müdahalesi, Sözleşmenin Yorumu, Sözleşmenin Tamamlanması, Sözleşmenin Değişen Hâl ve Şartlara Uyarlanması, 3. Bası, Yetkin Yayınları, Ankara, 2013. [KAPLAN, (2013)]

KAŞAK, Esra: "Sözleşmenin Niteliğine ve İşin Özelliğine Yabancı Olan Genel İşlem Koşulları (6098 sayılı TBK m. 21/2)", İnönü Üniversitesi Hukuk Fakültesi Dergisi, Cilt 3, Say1 1, Y11 2012, s. 415-429.

KELLER, Max: "Die Auslegung obligationenrechtlicher Verträge", Schweizerische Juristen-Zeitung, 57. Jahrgang, Heft 20, 15. Oktober 1961, s. 313-322.

KOCAYUSUFPAŞAOĞLU, Necip: Kocayusufpaşaoğlu/Hatemi/Serozan/ Arpacı Borçlar Hukuku Genel Hüküm, Birinci Cilt, 7. Bası, Filiz Kitabevi, İstanbul, 2017.

KOLLER, Alfred: Schweizerisches Obligationenrecht Allgemeiner Teil Handbuch des allgemeinen Schuldrechts, 4. Auflage, Stämpfli Verlag, Bern, 2017.

KRAMER, Ernst A./PROBST, Thomas: Obligationenrecht Allgemeiner Teil, 2. Auflage, Helbing Lichtenhahn Verlag, Basel, 2013.

KRAMER, Ernst A./PROBST, Thomas/PERRIG, Roman: Schweizerisches Recht der Allgemeinen Geschäftsbedingungen, Stämpfli Verlag, Bern, 2016.

KRAMER, Ernst A./SCHMIDLIN, Bruno: Berner Kommentar, Bd. VI Obligationenrecht, 1. Abteilung Allgemeine Bestimmungen, 1. Teilband Allgemeine Einleitung in das schweizerische Obligationenrecht und Kommentar zu Art. 1-18 OR, Stämpfli Verlag, Bern, 1986 (Herausgeber: MEIER-HAYOZ, Arthur).

KUT, Ahmet: Handkommentar zum Schweizer Privatrecht, 
Obligationenrecht Allgemeine Bestimmungen, Art. 1-183 OR, 3. Auflage, Schulthess Juristische Medien AG, Zürich/Basel/Genf, 2016 (Herausgeber: FURRER, Andreas/SCHNYDER, Anton K.).

LOCHER, Horst: Das Recht der Allgemeinen Geschäftsbedingungen, 2. Auflage, Verlag C.H. Beck, München, 1990.

LÖRTSCHER, Thomas: Vertragliche Haftungbeschränkungen im schweizerischen Kaufrecht unter besonderer Darstellung von Haftungsbeschränkungsklauseln in Allgemeinen Geschäftsbedingungen, Schulthess Polygraphischer Verlag AG, Zürich, 1977.

OĞUZ, Cemal: Genel İşlem Şartları ve İçerik Sınırları, Yayımlanmamış Doktora Tezi, Ankara, 1993.

OĞUZMAN, M. Kemal/ÖZ, M. Turgut: Borçlar Hukuku Genel Hükümler, Cilt 1, 12. Bası, Vedat Kitapçılık, İstanbul, 2014.

RAISER, Ludwig: Das Recht der Allgemeinen Geschäftsbedingungen, Hermann Gentner Verlag, Bad Homburg vor der Höhe, 1961.

RUSCH, Arnold F.: "Bitte recht feindlich - zur Auslegung allgemeiner Geschäftsbedingungen", Aktuelle Juristische Praxis, 23. Jahrgang, Jahr 2014, Ausgabe 2, s. 203-208.

SCHMIDT, Hubert: Beck'scher Online-Kommentar Bürgerliches Gesetzbuch, 48. Edition, Verlag C.H. Beck, München, 2018 (Herausgeber: BAMBERGER, Heinz Georg/ROTH, Herbert/HAU, Wolfgang/POSECK, Roman). (https://beck-online.beck.de erişim: 19. 02.2019)

SCHÖNENBERGER, Wilhelm/JÄGGI, Peter: Kommentar zum Schweizerischen Zivilgesetzbuch, V. Band: Obligationenrecht, Teilband V 1a, Art. 1-17 OR, 3. Auflage, Schulthess Polygraphischer Verlag, Zürich, 1973.

SCHULER, Alois G.: Über Grund und Grenzen der Geltung von Allgemeinen Geschäftsbedingungen, Verlag Stämpfli \& Cie, Bern 1978.

SCHWENZER, Ingeborg: Schweizerisches Obligationenrecht Allgemeiner Teil, 7. Auflage, Stämpfli Verlag, Bern, 2016. 
STADLER, Astrid: Jauernig Bürgerliches Gesetzbuch, 17. Auflage, Verlag C.H. Beck, München, 2018 (Herausgeber: STÜRNER, Rolf).

STUCKI, Marius: AGB-Kontrolle im schweizerischen Recht und im UNKaufrecht unter besonderer Betrachtung des revidierten Art. 8 UWG, Editions Weblaw, Bern, 2013. (https://www.ziv.unibe.ch/unibe/ portal/fak_rechtwis/c_dep_private/ziv/content/ e7688/e50302/e159370/ e205850/e459290/e459292/files648611/Stucki_Weblaw_ger.pdf, erişim: 24.02.2019)

TERCIER, Pierre/PICHONNAZ, Pascal/DEVELIOĞLU, H. Murat: Borçlar Hukuku Genel Hükümler, On İki Levha Yayıncılık, İstanbul, 2016.

WIEGAND, Wolfgang: "Die Auslegung Allgemeiner Geschäftsbedingungen", Privatrecht und Methode: Festschrift für Ernst A. Kramer, Helbing Lichtenhahn Verlag, Basel, 2004, s. 331-343.

YELMEN, Adem: Türk Borçlar Kanunu'na Göre Genel İşlem Şartları, Yetkin Yayınlar1, Ankara, 2014.

ZELLER, Ernst: Auslegung von Gesetz und Vertrag, Schulthess Polygraphischer Verlag AG, Zürich, 1989.

\section{KISALTMALAR}

ABGB Allgemeines Bürgerliches Gesetzbuch für Österreich vom 1. Juni 1811 (Avusturya Medeni Kanunu)

AGBG Gesetz zur Regelung des Rechts der Allgemeinen Geschäftsbedingungen vom 9. Dezember 1976

ALR Allgemeines Landrecht für die Preußischen Staaten vom 5. Februar 1794

BGB Bürgerliches Gesetzbuch für das Deutsche Reich vom 18. August 1896 (Alman Medenî Kanunu)

BGE Amtliche Sammlung der Entscheidungen des Schweizerischen Bundesgerichts (İsviçre Federal Mahkemesi Kararı)

BGer Schweizerisches Bundesgericht (İsviçre Federal Mahkemesi)

bkz. bakınız

CCF Code civil du 21 Mars 1804 (Fransız Medenî Kanunu) 
CCI Il Codice Civile Italiano R.D. 16 marzo 1942 (İtalyan Medenî Kanunu)

CCS Código Civil de 25 de julio de 1889 (İspanyol Medenî Kanunu)

CESL Proposal for a Regulation of the European Parliament and of the Council on a Common European Sales Law

CISG The United Nations Convention on Contracts for the International Sale of Goods (Milletlerarası Mal Satımına İlişkin Sözleşmeler Hakkında Birleşmiş Milletler Antlaşması)

dn. dipnot

eTKHK 23.02.1995 tarih ve 4077 say1lı (Eski) Tüketicinin Korunmas1 Hakkında Kanun

EWG Europäische Wirtschaftsgemeinschaft (Avrupa Ekonomik Topluluğu)

HD Hukuk Dairesi

m. madde

N Note, Randnote, Randnummer (Kenar Notu)

OR Bundesgesetz vom 30. Marz 1911 betreffend die Erganzung des Schweizerischen Zivilgesetzbuches (Fünfter Teil:

Obligationenrecht) (İsviçre Borçlar Kanunu)

PECL Principles of European Contract Law (Avrupa Sözleşme Hukuku İlkeleri)

RL Richtlinie (Direktif)

S. Sayfa

TBK 11.01.2011 tarih ve 6098 say1lı Türk Borçlar Kanunu

TCO Turkish Code of Obligations

TKHK $\quad$ 07.11.2013 tarih ve 6502 sayılı Tüketicinin Korunması Hakkında Kanun

TMK 22.11.2001 tarih ve 4721 sayılı Türk Medenî Kanunu

UNIDROIT International Institute for the Unification of Private Law

UWG Bundesgesetz gegen den unlauteren Wettbewerb vom 19. Dezember 1986 (Haksız Rekabet Kanunu)

vd. $\quad$ ve devamı

VVG Bundesgesetz über den Versicherungsvertrag vom 2. April 1908 (Sigorta Sözleşmesi Kanunu) 